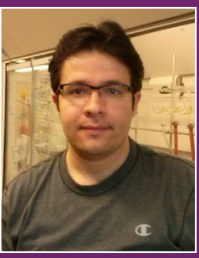

Ali Nazemi grew up in Miayneh, Iran. He obtained his BSc in Chemistry from K. N. Toosi University of Technology, Tehran Iran in 2005. He then moved to Canada and completed his $M S c$ in the area of Inorganic Chemistry at the University of Toronto under the supervision of Dr. Datong Song in 2009. He then decided to continue his graduate studies in the area of polymer and macromolecula chemistry. He is currently a $P h D$ candidate at The University of Western Ontario under the supervision of Dr. Elizabeth R. Gillies. His research focuses on curface functionalization of polymers surfece functionalization of polymersomes with dendrons for a wide range of biomedical applications and development of photodegradable dendrimers and dendrimer-based assemblies.

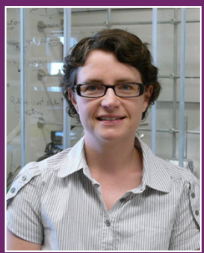

Elizabeth Gillies was raised in Ontario, Canada and obtained her BSc degree Kingston, Canada in 2000. She the moved to the University of California, Berkeley where she completed her $P h D$ degree in 2004 under the supervision of Jean Fréchet. Her research involved the development of dendrimer-based anticancer drug delivery vehicles as well as $\mathrm{pH}$-sensitive linkages for drug delivery applications. She then moved to Bordeaux, France where she performed postdoctoral work in the group of Ivan Huc, working on water-soluble helical aromatic oligoamide foldamers for biological applications. In 2006 , she began as an Assistant Professor at promoted to Associate Professor in 2006. Her research group works on the development of biodegradable polymers, polymer assemblies, and dendrimers for tissue engineering and drug delivery applications.

\section{Dendritic surface functionalization of nanomaterials: controlling properties and functions for biomedical applications}

\author{
Ali Nazemi', Elizabeth R. Gillies ${ }^{1,2, *}$
}

${ }^{1}$ Department of Chemistry, The University of Western Ontario, London, Canada, ${ }^{2}$ Department of Chemical and Biochemical Engineering, The University of Western Ontario, London, Canada

A wide variety of nanomaterials have demonstrated promise in medical applications such as drug delivery and imaging. In these applications, the surface chemistry of the materials is critical as it plays an important role in determining the toxicity and biodistribution behavior of the material. We review here the functionalization of nanomaterials with dendrons as an efficient method to alter the surface chemistry of the materials, introducing new properties and functions. Described here is the functionalization of superparamagnetic iron oxide nanoparticles (SPIO) with dendritic guanidines to enhance their transport into cells for magnetic resonance imaging applications. The introduction of dendrons bearing peripheral hydroxyls, amines, guanidines, carbohydrates and $\mathrm{Gd}(\mathrm{III})$ chelates to polymer vesicles (polymersomes) is also described. These dendritic moieties allow for modulation of toxicity, cell uptake, protein binding, and contrast agent efficiency, while at the same time allowing the stabilities of the polymersomes to be maintained. Thus, this approach holds promise for the development of a wide range of multifunctional materials for pharmaceutical applications.

Uniterms: Dendrimer. Superparamagnetic Iron Oxide Nanoparticles. Polymersome. Pharmaceutical applications.

Uma grande variedade de nanomateriais tem demonstrado aplicações médicas promissoras, tais como liberação de fármacos e em imagens. Nestas aplicações, a superfície química dos materiais é crítica, uma vez que exerce papel importante na determinação da toxicidade e comportamento de biodistribuição do material. Aqui, nós revisamos a funcionalização de nanomateriais, como dendrons, como método eficiente de alterar a superfície química destes compostos, introduzindo novas propriedades e funções. Descritos aqui estão nanopartículas superparamagnéticas de óxido de ferro (do inglês, SPIO), com guanidinas dendríticas para aumentar seu transporte para o interior das células, úteis em imagens de ressonância magnética. A introdução de dendrons contendo hidroxilas, aminas, guanidinas, carboidratos e quelatos de $\mathrm{Gd}(\mathrm{III})$ periféricos em vesículas poliméricas (polymersomes) também está descrita. Esses grupos dendríticos permitem a modulação de toxicidade, captura celular, ligação à proteína e eficiência como agente de contraste, enquanto que, ao mesmo tempo, permitem a manutenção da estabilidade das vesículas poliméricas. Assim, essa abordagem é promissora para o desenvolvimento de grande variedade de materiais multifuncionais para aplicações farmacêuticas.

Unitermos: Dendrímeros. Nanopartículas superparamagnéticas de óxido de ferro. Vesícula polimérica. Aplicações farmacêuticas.
*Correspondence: E. R. Gillies. Department of Chemistry, The University of Western Ontario. 1151 Richmond St., London, Canada N6A 5B7. E-mail: egillie@uwo.ca 


\section{INTRODUCTION}

In recent years, a diverse array of nanosized materials has been investigated for biomedical applications. For example, polymer assemblies such as micelles and vesicles have been widely investigated as carriers that can encapsulate drugs and release them in a controlled manner, while at the same time prolonging their circulation time and protecting them from premature degradation (Choudhury, He, 2012; Ohya et al., 2012; Tian et al., 2012). Various nanogels, microparticles and nanoparticles composed of biodegradable polymers have also been investigated with similar goals (Balmert, Little, 2012; Balmert, Little, 2012; Beck-Broichsitter et al., 2012; Patel et al., 2012). In medical imaging applications, superparamagnetic iron oxide nanoparticles (SPIO) have been demonstrated to provide contrast in a variety of applications owing to their ability to perturb local magnetic fields, leading to regions of hypointensity, or signal voids in images (Corot et al., 2006; Laurent et al., 2008; Villaraza et al., 2010). Semiconductor nanocrystals, termed quantum dots, have been shown to provide enhanced optical properties relative to conventional fluorophores, leading to their use in vivo in optical imaging and cell tracking, high resolution cellular imaging, and the study of various cellular processes at the molecular level (Cinteza, 2010). Gold nanoparticles of various shapes and sizes are one of the most widely used classes of bionanomaterials with applications in imaging, diagnostics, photothermal therapy, drug and gene delivery and other areas (Dykman, Khlebtsov, 2012).

While the bulk composition of a bionanomaterial is important for its function and long-term biocompatibility, the functionalities present at its surface are also critical. It is the surface of a material that will first comes into contact with the biological system and as such will play a major role in its toxicity and biodistribution behavior (Yang et $a l ., 2010)$. The surface can also provide sites for the introduction of drugs and moieties to target the material to specific sites in vivo (Pang et al., 2010; Pittet et al., 2006). Furthermore, the high levels of multivalency available at the surface of a nanomaterial can provide therapeutic properties by inhibiting undesirable multivalent interactions between host cells and pathogens including bacteria and viruses using ligands such as carbohydrates (Mammen et al., 1998; Rai et al., 2006).

Dendrimers are a class of macromolecules at the interface of polymer and synthetic organic chemistry. In contrast to hyperbranched polymers, which are prepared from branched (multifunctional) monomer units in a single polymerization reaction, resulting in incomplete branching and polydisperse materials, dendrimers are synthesized from branched monomer units in a stepwise manner, leading to monodisperse or very low polydispersity products (Tomalia et al., 1985; Frechet, Tomalia, 2001; Newkome et al., 2001). In addition, it is possible to achieve precise control over their molecular shape, dimensions, density, polarity, flexibility and solubility by choosing different building/branching units and surface functional groups (Tomalia et al., 1990; Caminade et al., 2005). Because of their monodispersities, high loading capacities, large-scale production, and bioconjugation capabilities, dendritic structures have been recognized to be ideal building blocks for biomedical applications (Gillies, Fréchet, 2005; Medina, El-Sayed, 2009; Rolland et al., 2009; Jain et al., 2010).

Generally, dendrimers are globe- or ellipsoidshaped, and they consist of three distinct regions: a central core, repeated branches, and surface functional groups (Aulenta et al., 2003). The central core should be a molecule with at least two reactive functional groups. The repeated branches are organized in a series of radially concentric layers called "generations" (Caminade et al., 2005). When iterative growth is conducted from focal point or core molecule containing one reactive group, wedge-shaped structures, commonly referred to as "dendrons" result (Figure 1). In addition to the interest in dendrimers and dendrons for biomedical applications, our group has also been interested in the use of dendrons for the surface modification of bionanomaterials. It was anticipated that their high multivalency would be advantageous in terms of displaying ligands or other functionalities at the surfaces of materials, while at the same time their bulky

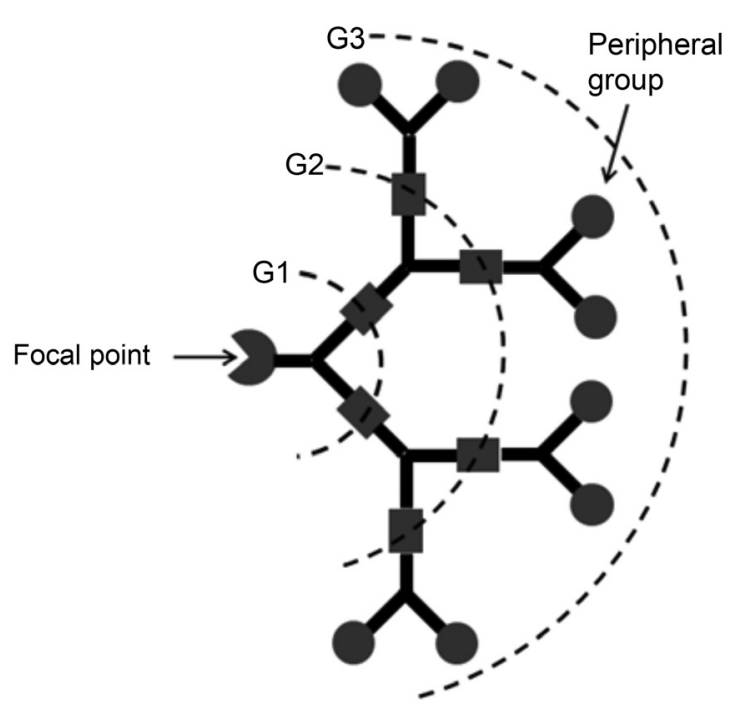

FIGURE 1 - Schematic representation of a dendron showing the focal point, generations (G1, G2, and G3 represent the first, second and third generations respectively), and peripheral groups. 
architecture would make these moieties readily available at the surface rather than buried within the polymer layer at the surface. Here we will provide an overview of our group's work in the introduction of dendritic groups to the surfaces of SPIO and polymersomes, and how this dendritic functionalization can be used to impart new properties and functions to these materials.

\section{DENDRITIC FUNCTIONALIZATION OF SPIO}

Magnetic resonance imaging (MRI) is an important non-invasive imaging technique for the study of biological processes, diagnosis of disease and the study of disease progression. MRI can be performed without contrast agents, but in many cases, the use of contrast agents can provide increased signal contrast between normal and diseased tissues, or aid in the understanding of biological phenomena. In addition to low molecular weight complexes based on Gd(III), (Caravan et al., 1999; Merbach, Toth, 2001; Terreno et al., 2010) which are commonly used clinically, the development of new agents based on SPIO has been of significant interest over the last couple of decades (Corot et al., 2006; Laurent et al., 2008; Villaraza et al., 2010). These nanoparticles induce local inhomogeneities in the magnetic field, resulting in regions of hypointensity in T2-weighted MR images. There are two primary means of administering SPIO. In one approach, SPIO is injected intravenously and arrives at the target site passively or through the conjugation of active targeting groups to the nanoparticle surface (Tsourkas et al., 2005; Lee et al., 2007). In another approach, in particular for the study of biological processes such as cancer metastasis and stem cell transplantation, cells are labeled with SPIO, implanted in vivo and then tracked by MRI (Bulte et al., 2001; Pittet et al., 2006; Foster et al., 2008).

It has been found that even single SPIO labeled cells can be detected in vivo by MRI, demonstrating the immense promise of cell tracking by MRI (Heyn et al., 2006). However, the ability to detect these labeled cells by MRI depends on the quantity of SPIO in the cells. While phagocytic cells such as macrophages can be readily labeled with SPIO, this labeling is more difficult for non-phagocytic cells such as cancer cells. For biomedical applications, SPIO is often coated with water-soluble polymers such as dextran (Weissleder et al., 1995) or poly (ethylene oxide) (PEO), (Li et al., 2005) which impart solubility and biocompatibility, but do not enhance the cellular uptake of SPIO. Various transfection agents have been used to enhance the uptake of SPIO, but the complexes formed with these agents are often polydisperse and challenging to control (Frank et al., 2003). Alternatively, cell-penetrating peptides such as HIV-Tat (Josephson et al., 1999; Lewin et al., 2000) or protamine (Pittet et al., 2006) have been used, but there may be limitations with respect to the large scale preparation of these peptides and concerns regarding immunogenicity. To address these issues, we prepared a dendritic cell penetrating agent and conjugated it to SPIO to provide enhanced cell uptake (Martin et al., 2008).

It had been previously demonstrated by the groups of Goodman, (Chung et al., 2004) Wender (Wender et al., 2005), and Harth (Huang et al., 2007) that it was possible to prepare dendrons functionalized at their peripheries with guanidines and that these could enhance the uptake of chromophores into cells in a manner similar to HIV-Tat and protamine, which contain high levels of the amino acid arginine. Thus, the concept of dendritic cell-penetrating agents seemed promising, but these agents had not previously been demonstrated to deliver large payloads such as nanoparticles into cells. A polyester dendron based on 2,2-bis(hydroxymethyl)propionic acid was selected as the dendritic scaffold due to its ease of synthesis, biodegradability and biocompatibility (Gillies et al., 2005). A dendron having a focal point alkyne and eight peripheral guanidines was prepared by divergent growth of the $3^{\text {rd }}$ generation dendron 1 from propargyl alcohol (Wu et al., 2005), installation of peripheral amines using a protected b-alanine anhydride, deprotection to the amine terminated dendron 2 (Li et al., 2007), coupling of a protected guanidine derivative, and finally deprotection to provide dendron 3 (Figure 2) (Martin et al., 2008). Using a fluorescein derivative of $\mathbf{3}$, it was demonstrated by flow cytometry studies with GL261 mouse glioma cells that the efficacy of the fluorescein labelled dendritic guanidine transporter was comparable to that of a fluorescein labelled HIVTat $_{47-57}$ oligopeptide (FITC-LC-YGRKKRRQRRR-NH ${ }_{2}$ ) (Martin et al., 2008).

SPIO coated with dextran and functionalized with azides, as well as a rhodamine dye was prepared with the aim of performing the conjugation reaction between the dendrons and the SPIO by highly chemoselective and functional group tolerant $\mathrm{Cu}(\mathrm{I})$ catalyzed "click" cycloaddition reactions (Lutz, Zarafshani, 2008). These cycloaddition reactions have been found to be very high yielding, even in water and in the presence of significant steric hindrance, and were therefore ideal for the conjugation of macromolecules such as dendrons to nanoparticles (Helms et al., 2004). Dendrons $\mathbf{1}-\mathbf{3}$ were conjugated to SPIO to provide SPIO with different dendritic surface coatings including hydroxyls, amines, and guanidines respectively (Figure 3) (Martin et al., 2008). Infrared (IR) spectroscopy was used to characterize the functionalized nanoparticles and it was found in the case of all three dendrons that the 


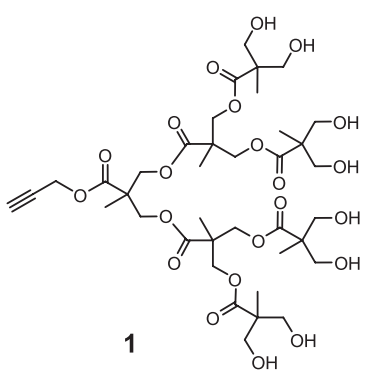

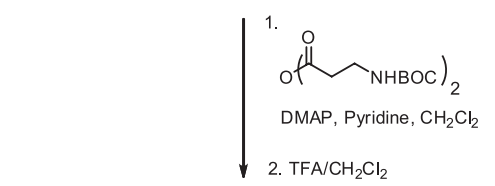
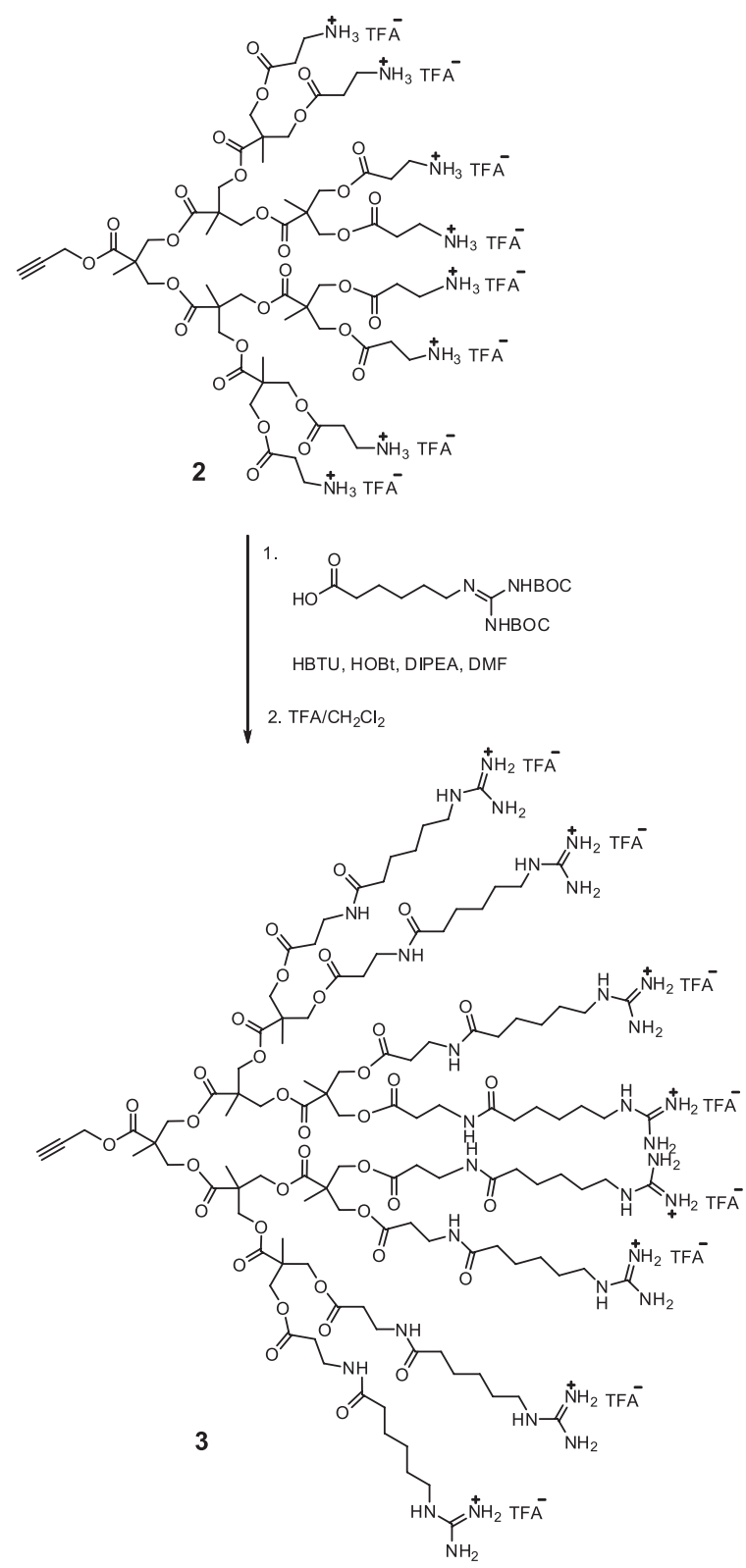

FIGURE 2 - Synthesis of hydroxyl 1, amine 2, and guanidine 3 functionalized dendrons. click reaction proceeded to completion with complete disappearance of the peak at $2100 \mathrm{~cm}^{-1}$ corresponding to the azide group. Dynamic light scattering (DLS) showed that the dendron-functionalized nanoparticles remained similar in size to the initial SPIO, with only a small increase in size and very minimal aggregation. In addition, transmission electron microscopy (TEM) was used to verify that the nanoparticle core was not affected. It was necessary to remove excess copper salts from the reaction mixture by dialysis against ethylenediaminetetraacetic acid (EDTA), followed by pure water.

The cell uptake of the SPIO into GL261 cells was investigated by flow cytometry based on the fluorescence of the rhodamine dye that was conjugated at the same density of each set of nanoparticles (Martin et al., 2008). After time points of $30 \mathrm{~min}$ and $2 \mathrm{~h}$ (Figure $4 \mathrm{a}$ ), only the cells incubated with the dendritic guanidine functionalized particles exhibited significantly increased fluorescence. These results were confirmed by confocal microscopy, which demonstrated that the SPIO was indeed taken up by cells and not simply adsorbed on the cell surface. It was also demonstrated that this enhanced uptake led to an enhanced MRI response (Figure 4b). GL261 cells were labeled with the dendritic guanidine functionalized SPIO, and then washed and pelleted. T2 measurements of unlabeled and labeled cell pellets demonstrated a 10-fold reduction in T2 value for the labeled cells. This significant difference in $\mathrm{T} 2$ values illustrates the utility of these nanoparticles for labeling cells for detection by MRI. The toxicities of the various nanoparticles were also investigated in GL261 cells using an MTT assay (Figure 4c). (Freshney, 2000) Consistent with previous experiments demonstrating the high biocompatibilities of dendrimers based on 2,2-bis(hydroxymethyl)propionic acid (Gillies et $a l ., 2005)$, the dendritic hydroxyl and the dendritic amine functionalized SPIO had a very similar toxicity to the dextran coated particles that are widely used for cell labeling applications. The dendritic guanidine functionalized particles exhibited somewhat increased toxicity at higher concentrations, but they remained relatively non-toxic at the low concentrations used for cell labeling. It is possible that their toxicity at higher concentrations arises from their ability to penetrate and create defects in cell membranes, as has been observed for various polycationic nanoparticles and transporters (Leroueil et al., 2008).

Overall, this study demonstrated several key findings. First, it represented the first successful example of the transport of a biologically relevant nanoparticle cargo by a dendritic guanidine transporter. The resulting system can provide improved labeling of cells with SPIO for enhanced sensitivity in cellular MRI. In addition, it demonstrated 

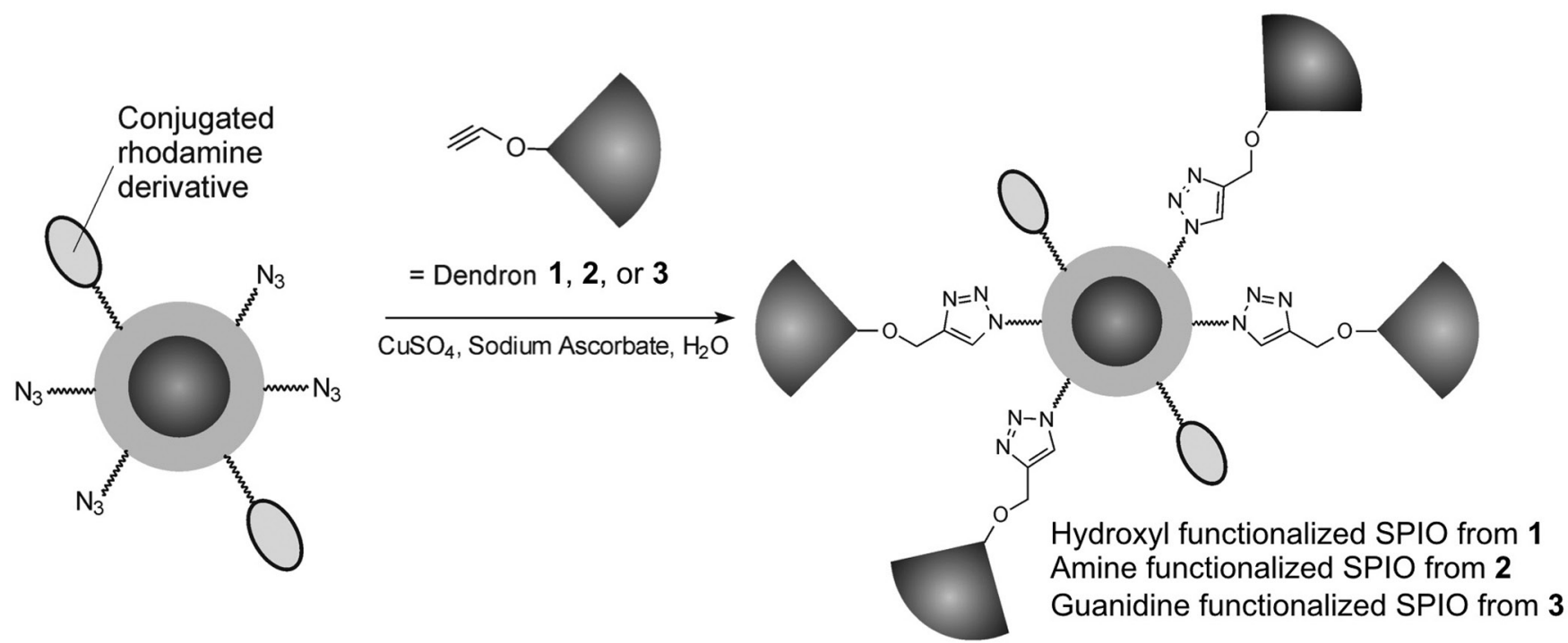

FIGURE 3 - "Click" conjugation of dendrons 1, 2, and $\mathbf{3}$ to azide functionalized SPIO to provide dendritic hydroxyl, amine, and guanidine functionalized SPIO respectively (Martin et al., 2008).

a) Control, hydroxyl, and amine functionalized particles

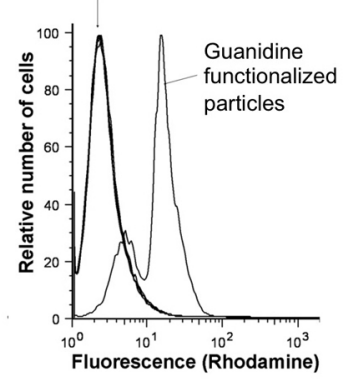

b)
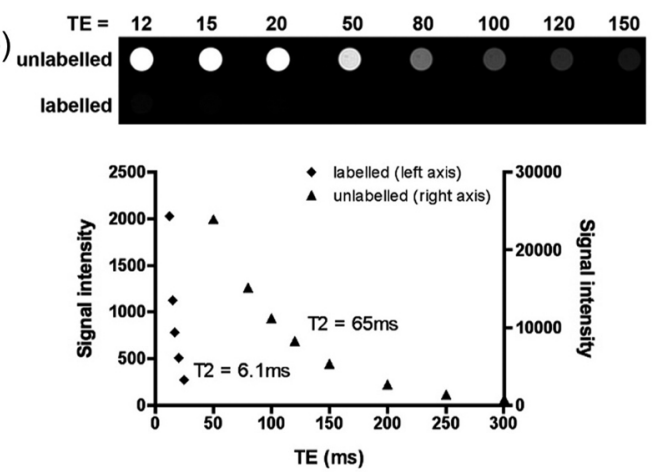

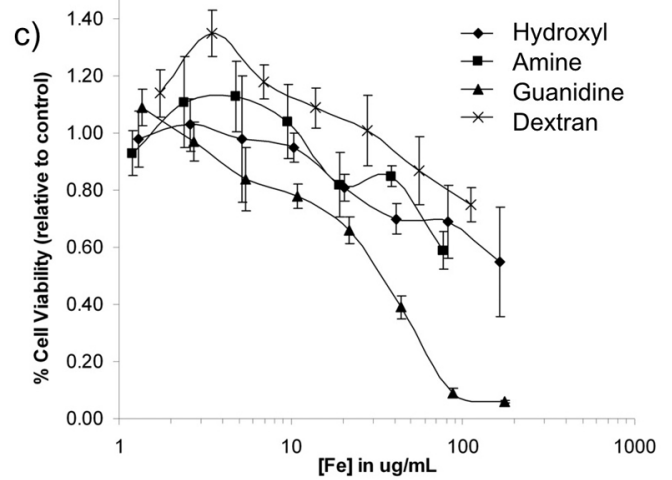

FIGURE 4 - a) Flow cytometry analyses of GL261 cells following incubation with dendron functionalized SPIO at a concentration of $25 \mu \mathrm{g} \mathrm{Fe} / \mathrm{mL}$ for $2 \mathrm{~h}$; b) MRI signal intensity of unlabelled cells and cells labelled with dendritic guanidine functionalized SPIO, measured at $3 \mathrm{~T}$ using a spin echo sequence with varying echo times (TE); c) Viability of GL261 cells after 24 h incubation with dendron functionalized SPIO, as measured by the MTT assay. Error bars represent standard deviations on 3 measurements (Martin et al., 2008).

that dendrons are an effective means of presenting biologically relevant functionality on a nanoparticle surface and a synthetic means for expanding this dendritic functionalization approach to a diverse array of azide functionalized nanomaterials.

\section{DENDRITIC FUNCTIONALIZATION OF POLYMERSOMES}

Over the past few decades, amphiphilic copolymers have been demonstrated to assemble into a vast array of morphologies ranging from spherical micelles (Alexandridis, Lindman, 2000) to cylindrical micelles (Cai et al., 2007), helical rods (Cornelissen et al., 1998), toroids
(Pochan et al., 2004), vesicles (Discher, Eisenberg, 2002; Zhang, Eisenberg, 1995), tubes (Yan et al., 2004), and multicompartment cylinders (Cui et al., 2007). Among these, polymer vesicles in particular, commonly referred to as polymersomes have received increasing attention. Interest in polymersomes can likely be attributed in part to their structural similarity to phospholipid vesicles (liposomes), which are important components of biological systems where they serve as cell membranes, and they have also been widely investigated in areas such as drug and gene delivery (Torchilin, Weissig, 2003). Like phospholipid vesicles, polymersomes possess a hydrophobic membrane as well as an aqueous core, allowing for the incorporation of both hydrophilic and hydrophobic mol- 
ecules, and thus potentially multifunctional properties. In comparison with liposomes, polymersomes have been shown to exhibit properties such as increased strength and decreased permeability, which may be advantageous in their application as synthetic biomaterials (Discher et al., 1999; Discher, Eisenberg, 2002). Indeed, over the past decade there have been many reports emerging on their use as carriers of proteins (Ranquin et al., 2005; Liu et al., 2010), hydrophilic drugs (Ahmed et al., 2006; Yang et al., 2010), and imaging agents (Ghoroghchian et al., 2005).

As described above, the surface chemistry of polymersomes is critical in terms of controlling their interactions with biological systems. The introduction of dendritic groups via "click" [3+2] cyloaddition reactions of azide functionalized polymersomes with dendrons having focal point alkynes provides the opportunity to alter the surface chemistry in a single step without changing the block copolymers comprising the polymersome membranes. This provides a unique opportunity to impart new biological properties and functions.

In our initial work, as shown in Figure 5, polymersomes composed of the amphiphilic linear diblock copolymer poly(butadiene- $b$-ethylene oxide) (PBD-PEO) were used (Li et al., 2007). An azide was introduced to the polymer terminus and polymersomes were prepared containing varying ratios of the azide and hydroxyl terminated polymers. Dendron $\mathbf{2}$ having an alkyne focal point and peripheral amine groups was used and $\sim 1$ rhodamine dye per dendron was introduced to the dendron's periphery in order to track and quantify the conjugation reaction. This dendron was reacted with the polymersomes under standard click conditions involving $\mathrm{CuSO}_{4}$, sodium ascorbate, and the ligand bathophenanthrolinedisulfonic acid. It was found that the use of this ligand prevented the adsorption of copper ions to the dendritic amines. The conjugation yields for the various polymersomes were quantified based on the UV-visible absorbance of the rhodamine dye on the dendrons.

As shown in Figure 6a, it was found that the conjugation yields were typically greater than $60 \%$ at low surface azide content ( $£ 20 \%$ ) (Li et al., 2007). This was greater than expected as $\sim 50 \%$ of the azides would be on the interior of the polymersome and it was not expected that the dendrons could pass through the membrane into the polymersome's aqueous core. However, it is likely that through various processes, some interior azides can move to the
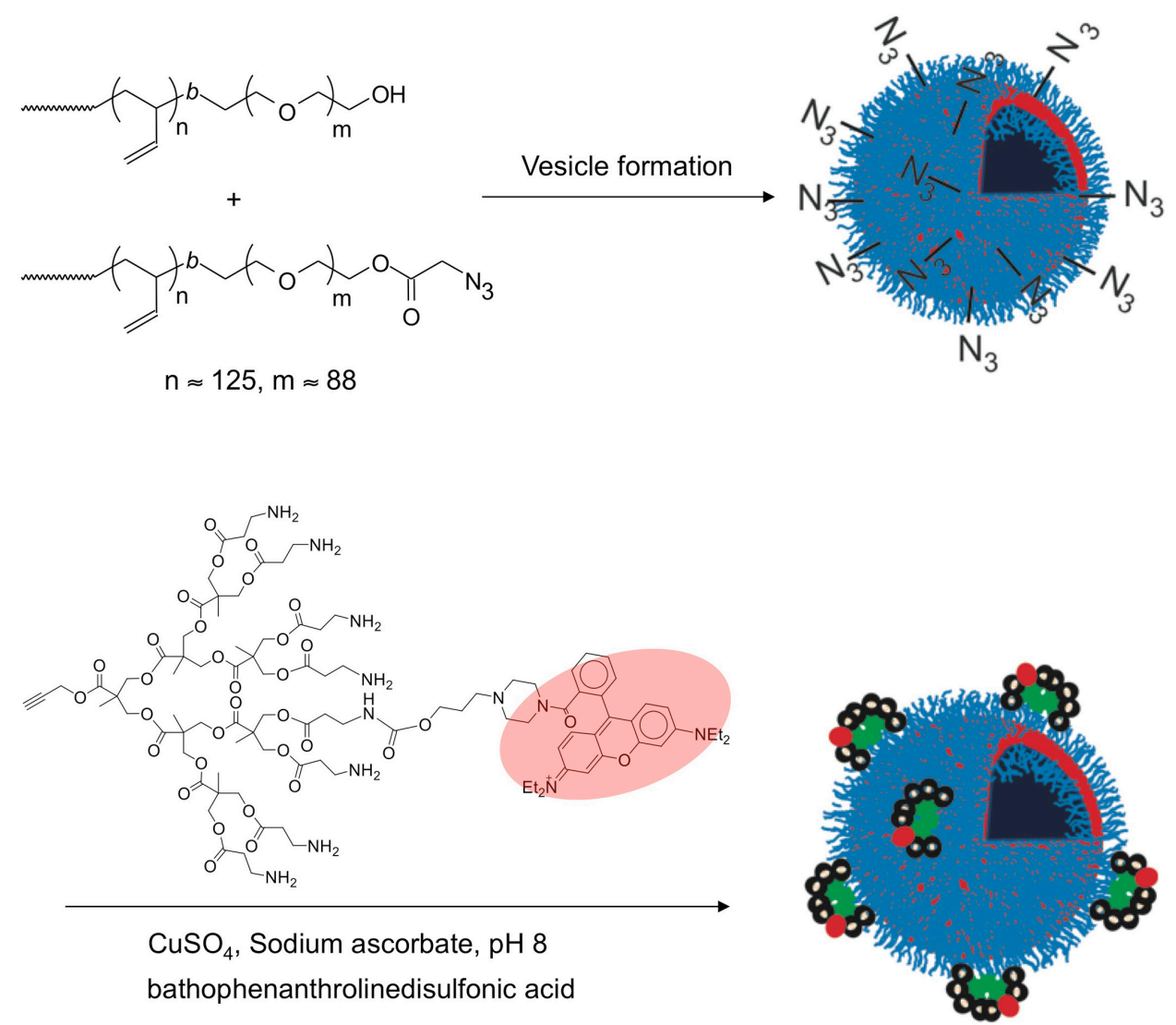

FIGURE 5 - Schematic showing the functionalization of polymersomes bearing peripheral azide groups with dendrons having focal point alkynes. 
a)

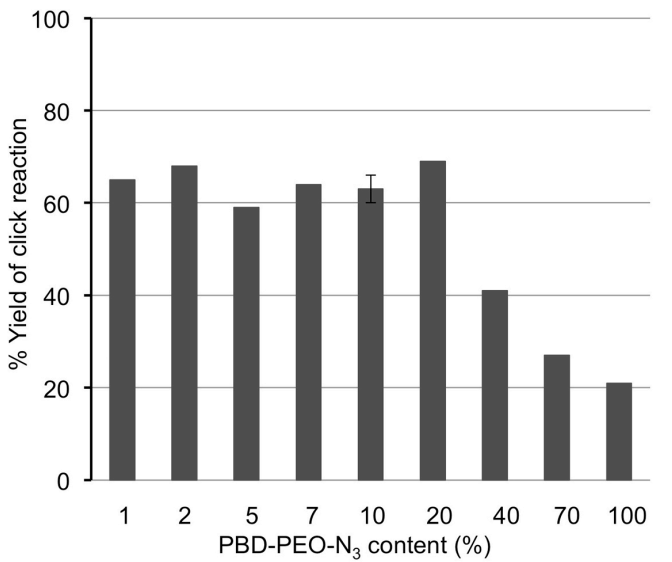

b)

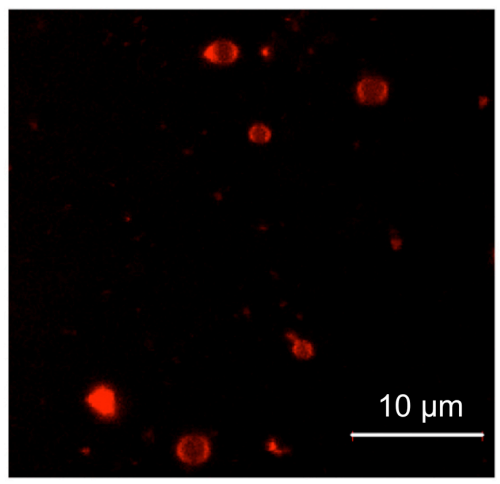

FIGURE 6 - a) Yield for the "click" conjugation between the dendron and polymersomes as a function of polymersome PBD-PEO-N content (remainder is PBD-PEO-OH); b) Well dispersed polymersomes resulting from the conjugation of dendron to polymersomes composed of 5:95 PBD-PEO-N 3 :PBD-PEO-OH.

surface during the $24 \mathrm{~h}$ reaction. At higher azide content, the conjugation yields dropped off dramatically. This was attributed to steric hindrance at the polymersome surface due to the bulky nature of the dendrons. As these polymersomes were micron-sized, they were also observed by fluorescence confocal microscopy. That the polymersomes were fluorescent was further confirmation of the successful conjugation of the rhodamine-labeled dendrons (Figure 6b). In addition, well-dispersed polymersomes were observed at low azide content. On the other hand, at higher azide content, significant aggregation was observed which may be attributed to either a disruption of the hydrophilic/ hydrophobic balance within the polymersome membrane upon dendron conjugation, or to interactions between the dendrons on different polymersomes. However, at azide content $£ 20 \%$ this method was highly promising for the surface functionalization of polymersomes.

In a subsequent study, the surface functionalization of PBD-PEO polymersomes with dendritic versus non-dendritic ligands was studied (Martin et al., 2009). Mannose was selected as the ligand as its multivalent binding to targets such as Concanavalin $\mathrm{A}$ (Con A) has been extensively investigated and a number of assays have been developed to evaluate this binding (Bittiger, 1976; Roy, 1996; Kanai et al., 1997; Gestwicki et al., 2002). Mannose functionalized dendron 4 (Figure 7), and a small molecule mannose derivative with an azide functionality were prepared (Martin et al., 2009). A dye-labeled version of dendron $\mathbf{4}$ was used to quantify the conjugation to polymersomes and similar results to those described above for dendron 2 were obtained. As shown in Figure 7 a dendritic mannose polymersomes were prepared by the "click" conjugation of dendron $\mathbf{4}$ to polymersomes con- taining 5\% azide functionalized PBD-PEO. Non-dendritic mannose polymersomes were prepared by first conjugating the azide functionalized mannose to an alkyne-terminated PBD-PEO, and then assembly of polymersomes from a 50:50 mixture of mannose and hydroxyl-terminated polymers (Figure $7 \mathrm{~b}$ ). These quantities were selected in order to provide the same overall mannose content in the dendritic and non-dendritic polymersomes, but displayed in a different manner.

The dendritic and non-dendritic polymersomes were compared using a hemagglutination assay. In the presence of the protein Con A, red blood cells cluster due to interactions of cell surface carbohydrates with the protein. When mannose is present at a sufficiently high concentration, Con A binds preferentially to mannose and the clustering of the blood cells is inhibited. Comparisons of the minimum mannose concentration required to inhibit the agglutination can provide relative binding affinities of mannose-based ligands, which was the main point of interest in this study. The known small molecule ligand $\alpha$-D-methyl mannopyranoside was used as a point of reference in this study. Despite their multivalency, the non-dendritic polymersomes provided only a very modest 3.7-fold enhancement in affinity on a per mannose basis. In contrast, the dendritic mannose functionalized polymersomes provided a much greater 42 -fold increase in relative binding affinity.

This enhancement relative to the non-dendritic system was attributed to several factors including the relatively rigid display of ligands on the dendritic scaffold resulting in an entropic advantage (Mammen et al., 1998), the ability of the dendritic scaffold to overcome steric inhibition of binding by the PEO layer (Lin et al., 


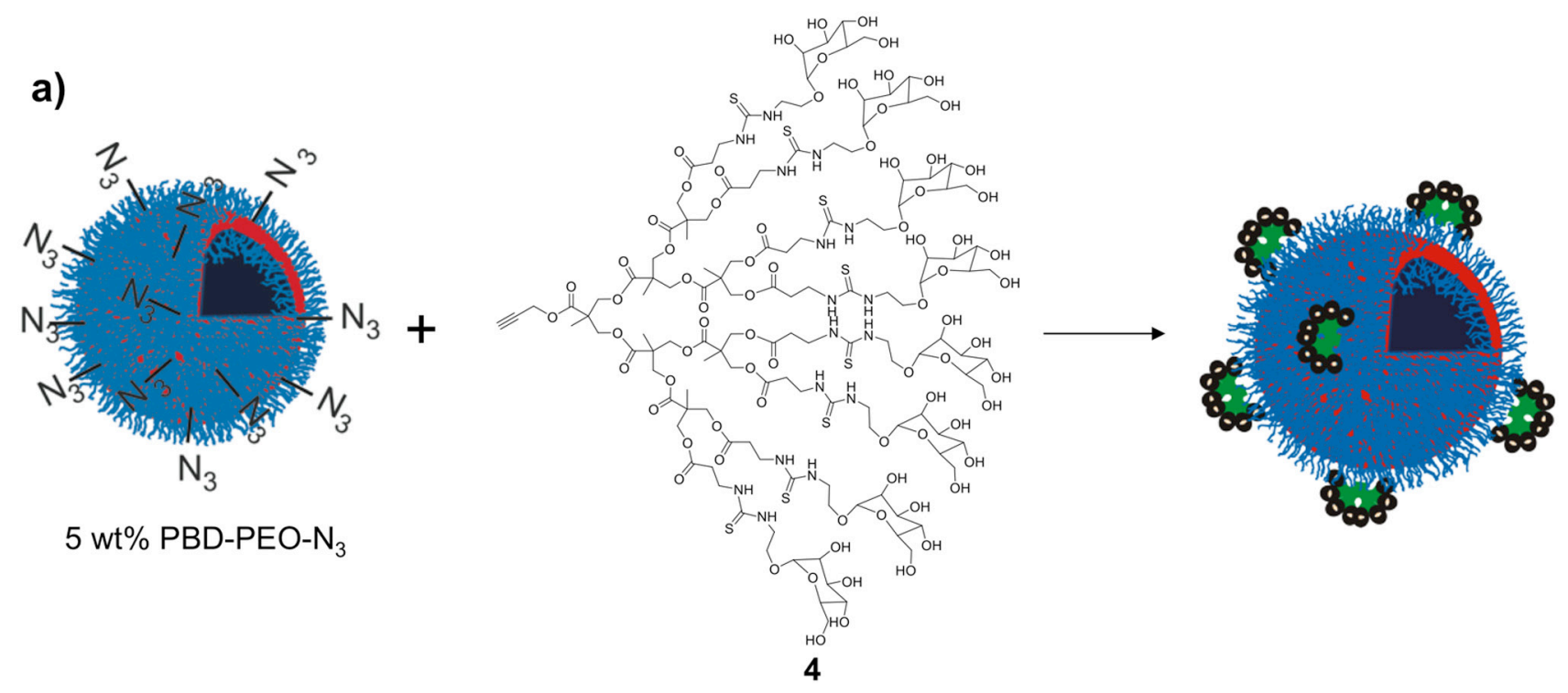

b)
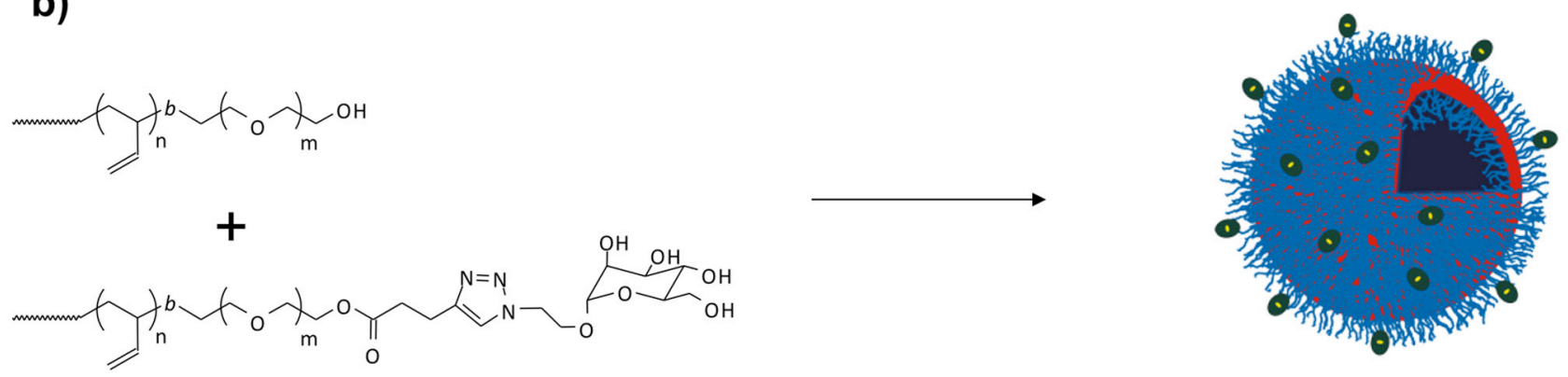

FIGURE 7 - Schematic for the preparation of a) dendritic mannose polymersomes; b) non-dendritic mannose polymersomes.

2004), and an enhanced "proximity" effect resulting from the clustered display of ligands on the dendron (Lundquist, Toone, 2002). Through the preparation of the analogous dendritic and non-dendritic systems on dextran coated SPIO, it was demonstrated that these enhancements were generalizable to other nanoparticles and other polymer coatings in addition to PEO (Martin et al., 2009). Thus, this study revealed that it is important to consider carefully not only the choice of biological ligand, but also the mode in which it is conjugated to the surface in order to exploit the benefits of nanomaterials. Furthermore, it showed that dendritic scaffolds are an effective means of displaying biological ligands on surfaces.

As described above, the dendritic surface functionalization approach provides a means of easily altering the polymersome surface chemistry in a single step. This provided the opportunity to explore the effect of the dendritic functionalization with different surface moieties on the physical and biological properties of polymersomes
(Amos et al., 2012). In this case, in contrast to the micrometer-sized polymersomes described above, the PBD-PEO polymersomes were extruded through a $100 \mathrm{~nm}$ membrane to produce polymersomes with diameters of 100-200 nm that would be more suitable for biological applications. The azide and alkyne [3+2] cycloaddition was used to conjugate dendrons $\mathbf{1}, \mathbf{2}$, and $\mathbf{3}$ to polymersomes composed of $20 \%$ azide termined PBD-PEO (Figure 8 ). Because of the aggregation that had been previously observed upon conjugation of dendrons to vesicles with higher azide content (Li et al., 2007), we were interested in more subtle effects of the dendritic surface functionalization on the polymersome stability at lower azide content. This was probed first by measuring the release rate of an encapsulated rhodamine dye from polymersomes functionalized with the different dendrons. As this dye molecule was known to traverse the polymersome membrane due to its balance of hydrophilicity and hydrophobicity this probed the effects of the dendrons on the membrane permeabil- 


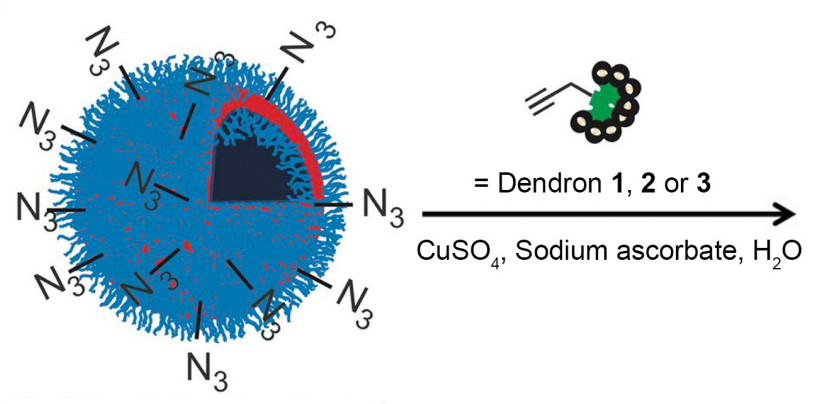

$20 \mathrm{wt} \%$ azide functionalized polymer

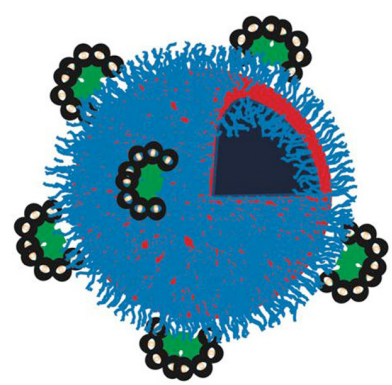

Hydroxyl functionalized polymersomes from 1 Amine functionalized polymersomes from 2 Guanadine functionalized polymersomes from 3

FIGURE 8 - "Click" conjugation of dendrons 1, 2, and $\mathbf{3}$ to azide functionalized PBD-PEO polymersomes to provide dendritic hydroxyl, amine, and guanidine functionalized polymersomes respectively (Amos et al., 2012).

ity. No significant differences in the release rates of the dye from naked or the different dendritic functionalized polymersomes were observed, and in each case complete release was observed over a period of 10-15 h. The release of a rhodamine-labeled bovine serum albumin was also investigated. Because of its large size and high polarity/ charge, this protein was not expected to diffuse across the intact polymersome membrane and thus disruption of the membrane would be required for release. Again it was found that there were no significant differences in the release rates among the naked or different dendritic polymersomes, and as expected the release was much slower for the protein, requiring 1-2 weeks to reach completion. Overall, these results demonstrated that the dendritic functionalization approach did not impart any inherent instability to the polymersomes.

The effects of the dendritic groups on the toxicities and cell uptakes of the polymersomes were also investi- gated (Amos et al., 2012). In an MTT assay, as shown in Figure $9 \mathrm{a}$, it was found that up to $1 \mathrm{mg} / \mathrm{mL}$ of polymer, the highest concentration evaluated, no significant toxic effects were observed for any of the samples except the dendritic guanidine functionalized polymersomes. This was not surprising in light of the previous results with the dendritic guanidine functionalized SPIO and can likely be attributed to the same causes (Martin et al., 2008). However, it was possible to administer these polymersomes without significant toxicity at lower concentrations. The cell uptake of the polymersomes was of particular interest due to the possibility of using polymersomes to encapsulate and deliver molecules such as DNA/RNA (Lomas et al., 2007; Christian et al., 2009; Cheng et al., 2011) and proteins, (Demirgoz et al., 2009; Cheng et al., 2011) which cannot normally diffuse through cell membranes. In this case, the uptake was studied using rhodamine-labeled polymersomes and the uptake was quantified by confocal
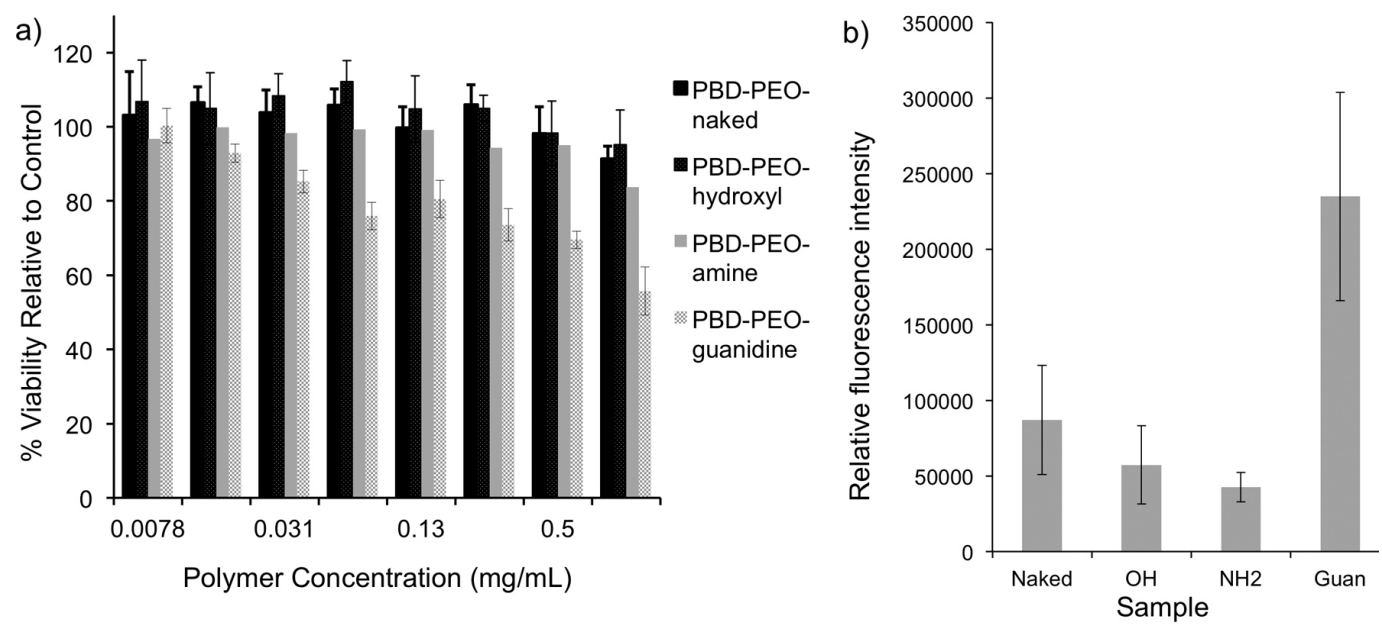

FIGURE 9 - a) Toxicity of naked and dendron functionalized PBD-PEO polymersomes as measured by an MTT assay following 48 hour of incubation with HeLa cells; b) Quantitative comparison of the uptake of naked and dendritic hydroxyl, amine, and guanidine functionalized polymersomes in HeLa cells following a $1 \mathrm{~h}$ incubation at $37^{\circ} \mathrm{C}$, as measured by fluorescence confocal microscopy. 
microscopy (Amos et al., 2012). It was found that the dendritic guanidine functionalized polymersomes exhibited a statistically significant increase in uptake relative to all of the other polymersome samples, showing that the dendritic guanidine is a versatile tool for the delivery of nanomaterials into cells (Figure 9b). The mechanism of cell uptake was investigated through temperature-dependent studies and by examining the colocalization of vesicles with LysoTracker TM Blue. These studies suggested that endocytosis pathways likely play a major role in the internalization of these systems, though direct translocation may also play a small role.

While the above work demonstrated several important properties and functions that can be imparted through dendritic surface functionalization of polymersomes, a limitation was the use of PBD-PEO. This copolymer is not biodegradable and while PEO is well established for biomedical applications, the PBD block presented concerns with respect to the long term behavior in vivo. To address this limitation, a system based on polycaprolactone (PCL)PEO block copolymers was developed. PCL is a well known biodegradable polymer that is currently approved for uses in tissue engineering (Jenkins et al., 2006; Lam et al., 2007) and drug delivery (Chandra, Rustgi, 1998; Sinha et al., 2004). A synthetic method was developed for the preparation of azide terminated (5) and hydroxyl terminated (6) PCL-PEO and these block copolymers were assembled into polymersomes by a nanoprecipitation method involving the dissolution of the copolymer in tetrahydrofuran (THF), followed by a gradual addition of water, and finally dialysis against water to remove the THF (Figure 10a) (Nazemi et al., 2011). This led reproducibly to polymersomes with diameters of $\sim 140 \mathrm{~nm}$. It was possible to extrude these polymersomes to reduce their sizes to $\sim 65 \mathrm{~nm}$ in diameter, an ideal size for in vivo circulation. By reducing the PCL content in the block copolymers, it was also possible to prepare micelles with diameters of $25 \mathrm{~nm}$ using a similar protocol (Figure 10b) (Nazemi et al., 2011).

The click functionalizations of the polymersomes and micelles with dendrons $\mathbf{2}$ and $\mathbf{3}$ were studied as described above for the PBD-PEO polymersomes (Nazemi et al., 2011). With rhodamine-labelled version of dendron 2, which had previous been studied quantitatively with PBD-PEO polymersomes, similar conjugation yields to the PCL-PEO polymersomes were obtained, as measured by UV-visible spectroscopy (Figure 11a). The yields were somewhat lower for rhodamine-labelled version of dendron 3, which was expected based on its larger size. For the micelles, it was expected that at low azide loading the conjugation yield should approach $100 \%$ as all of the azides should be on the micelle surface. However, as shown in Figure 11b, this was not the case and the yields were similar to those obtained for the polymersomes. The

a)

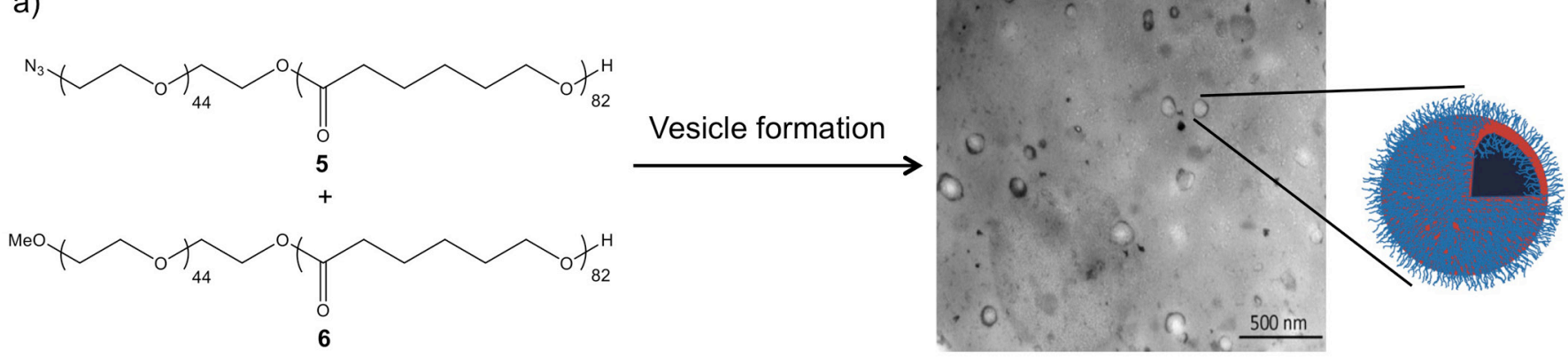

b)

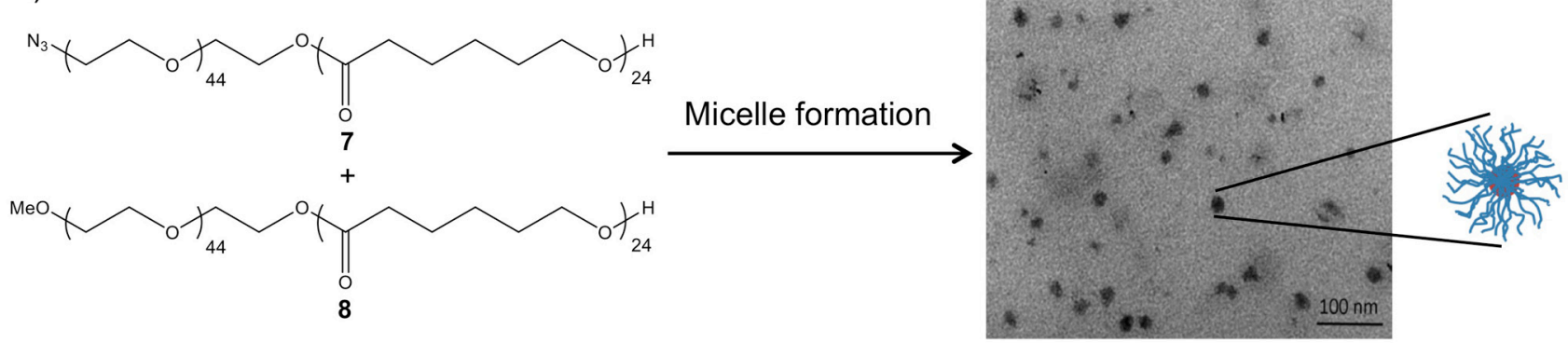

FIGURE 10 - Assembly of PCL-PEO diblock copolymers into a) vesicles; b) micelles. 
a)

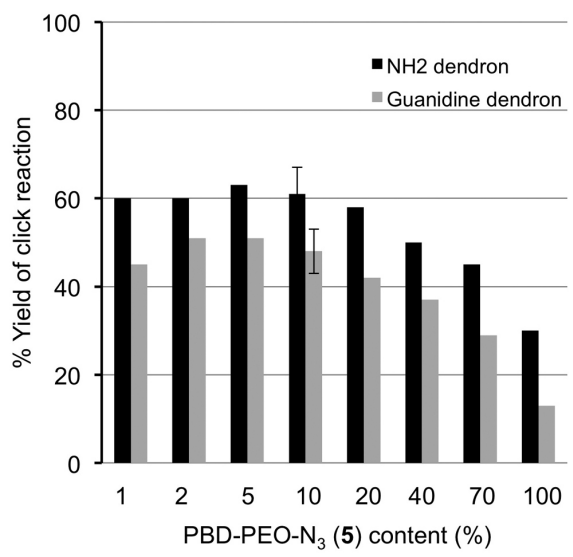

b)

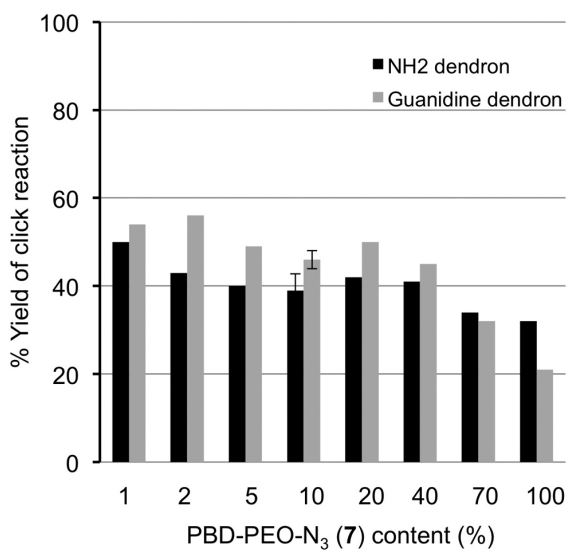

FIGURE 11 - Yields for the "click" conjugation between the rhodamine-labelled versions of dendrons $\mathbf{2}$ or $\mathbf{3}$ and PCL-PEO a) vesicles, and b) micelles as a function of PCL-PEO- $\mathrm{N}_{3}$ content (remainder is PCL-PEO-OMe).

reasons for these lower yields are still unclear at this time, but can perhaps be related to the large size of the dendrons relative to the micelles.

TEM was used to confirm that both the micelles and polymersomes remained intact following the dendron conjugation. However, upon removal of the excess dendron by dialysis, significant aggregation was observed for the polymersomes, even at relatively low azide content, unlike for the PBD-PEO polymersomes. Thus, the PEO-PCL polymersomes appear to be more sensitive to aggregation. The reasons for the differences between the two different polymersomes is not clear, but aggregation is believed to result from the cationic charges on dendrons $\mathbf{2}$ and $\mathbf{3}$ as studies with hydroxyl terminated dendrons, even of higher generation did not result in aggregation. The removal of the excess dendron by dialysis at a variety of $\mathrm{pHs}$ and ionic strengths was investigated with the aim of preventing aggregation was investigated, but unfortunately the aggregation could not be prevented. The micelle systems proved much less susceptible to aggregation, a result likely attributable to their different morphologies. Thus, this work demonstrated that the dendritic functionalization approach could be extended to biodegradable PCL-PEO polymersomes and also to micelles formed from these polymers. Aggregation was problematic for polymersomes functionalized with dendrons bearing cationic peripheral groups, but not for those with neutral hydroxyl groups, and not for the micelles, even with cationic dendrons.

The above work lay the groundwork for the use of PCL-PEO polymersomes in specific biomedical applications. In a first demonstration of their utility, PCLPEO polymersomes were used to prepare an enhanced Gd(III)-based MRI contrast agent (Nazemi et al., 2012).
As described above in the context of SPIO, MRI is an important noninvasive imaging modality. Most clinically used contrast agents for MRI are based on small molecule chelates of Gd(III) (Caravan et al., 1999; Merbach, Toth, 2001; Terreno et al., 2010). While the availability of these agents has enabled significant developments in MRI, they do suffer from some significant limitations including their low longitudinal relaxivities $\left(r_{l}\right)$, typically in the range of $3-5 \mathrm{mM}^{-1} \mathrm{~s}^{-1}$, and their short circulation half lives (Caravan, 2006). These limitations result in the requirement for large doses and also limits their applicability in molecular imaging (Prince et al., 2009). To address these limitations, Gd(III) complexes have been conjugated to a wide variety of macromolecular scaffolds including dendrimers (Gang et al., 2010; Kobayashi, Brechbiel, 2005), linear polymers (Allen et al., 2006), proteins (Caravan et al., 2002), viral particles (Hooker et al., 2007), micelles (Accardo et al., 2004), liposomes (Schühle et al., 2010), and polymersomes (Cheng, Tsourkas, 2008; Grüll et al., 2010). This can result in improvements in $r_{1}$ values due to the slower tumbling rates of macromolecules and the resulting increases in the rotational correlation times of the Gd(III) (Caravan, 2006; Villaraza et al., 2010). In addition, macromolecular systems can exhibit prolonged blood circulation times (Gillies et al., 2005). Polymersomes are a particularly promising scaffold for the development of enhanced MRI contrast agents due to their inherently multifunctional character as different functions such as multimodal imaging agents and drug molecules can be incorporated onto their surface, inside the membrane, or inside the aqueous core.

In this study, it was hypothesized that while the conjugation of Gd(III) complexes to high generation dendrimers is known to enhance their relaxivities, im- 
mobilization on the polymersome surface should provide further enhancements in relaxivity, while opening possibilities for the multifunctional opportunities described above (Nazemi et al., 2012). To evaluate this hypothesis, three different contrast agents were prepared and studied. As shown in Figure 12a, an isothiocyanate derivative 9 of the clinically used diethylenetriaminepentaacetic acid (DTPA) chelate was reacted with dendron 2 to provide the dendritic chelate $\mathbf{1 0}$ in which Gd(III) was coordinated to provide the dendritic Gd(III) complex 11. Dendron 11 was coupled to PCL-PEO polymersomes having a diameter of $140 \mathrm{~nm}$ to provide the dendritic polymersome contrast agent 12. On the other hand, as shown in Figure 12b, 9 was first reacted with propargyl amine to obtain the clickable DTPA derivative 13. This molecule was then used to chelate $\mathrm{Gd}(\mathrm{III})$ to provide compound $\mathbf{1 4}$ which was then coupled to polymersomes to provide the non-dendritic polymersome contrast agent $\mathbf{1 5}$.

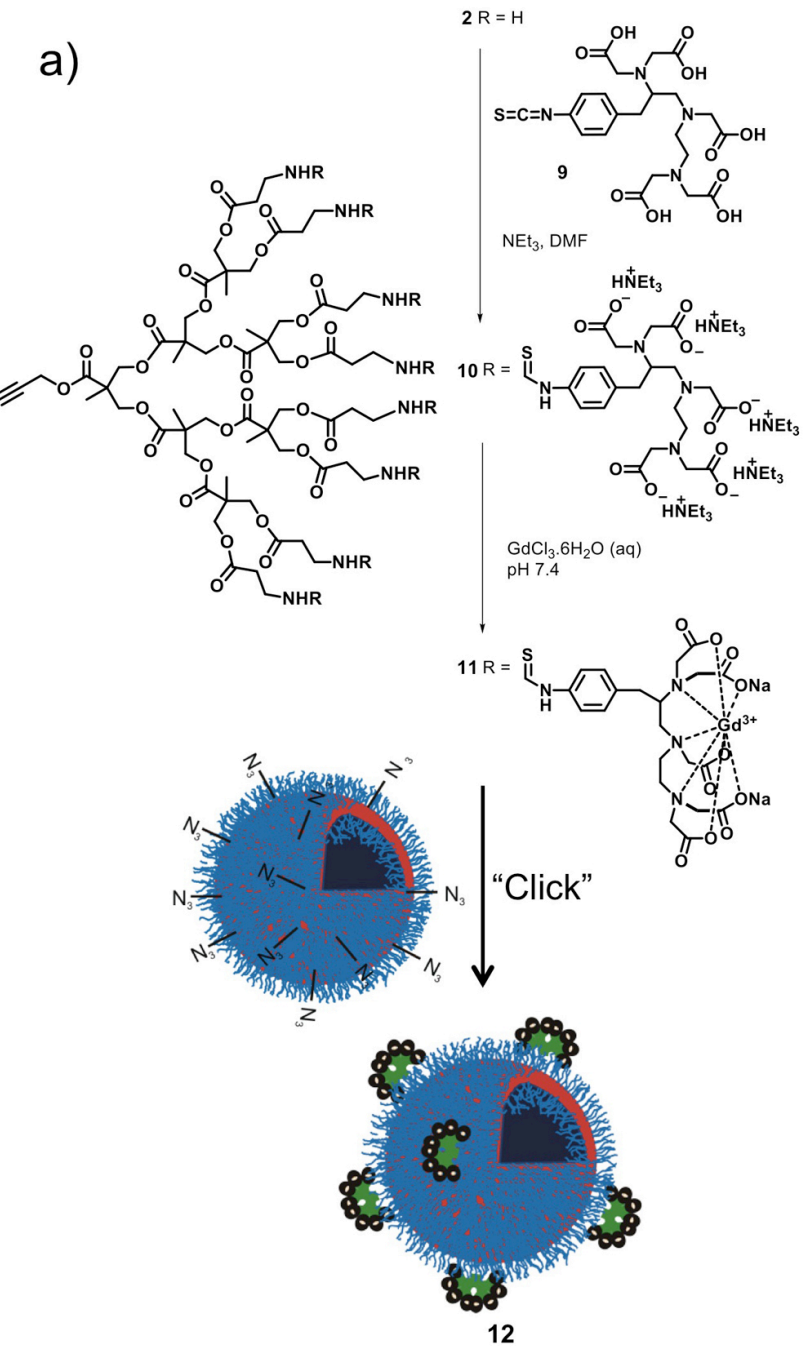

The relaxivities of agents $\mathbf{1 1}, \mathbf{1 2}$, and $\mathbf{1 5}$ were measured at various magnetic field strengths using a field cycling relaxometer (Nazemi et al., 2012). On a per Gd(III) basis, dendron 11 and polymersomes 12 and $\mathbf{1 5}$ exhibited $r_{1}$ values of $12.1 \pm 0.3,26.1 \pm 1.2$, and $10.6 \pm 0.4 \mathrm{mM}^{-1} \mathrm{~s}^{-1}$, respectively $(20 \mathrm{MHz}, 298 \mathrm{~K})$. In comparison with the clinical agent Magnevist ${ }^{\circledR}$ (Gd(III)-DTPA) which has a relaxivity of $4.6 \mathrm{mM}^{-1} \mathrm{~s}^{-1}$ under the same conditions, this corresponds to 2.6-, 5.7-, and 2.3-fold increases in $r_{l}$ for dendron 11, and polymersomes $\mathbf{1 2}$ and $\mathbf{1 5}$ respectively. The result for the dendron was in the expected range based on results for previous dendritic Gd(III) chelates of similar dendrimer generation (Kobayashi, Brechbiel, 2005; Gang et al., 2010). The enhancement in relaxivity relative to the small molecule was attributed to the crowded nature of the dendron periphery, which inhibits free rotation of the Gd(III) complexes, thus increasing the rotational correlation time. The enhancement for the

b)
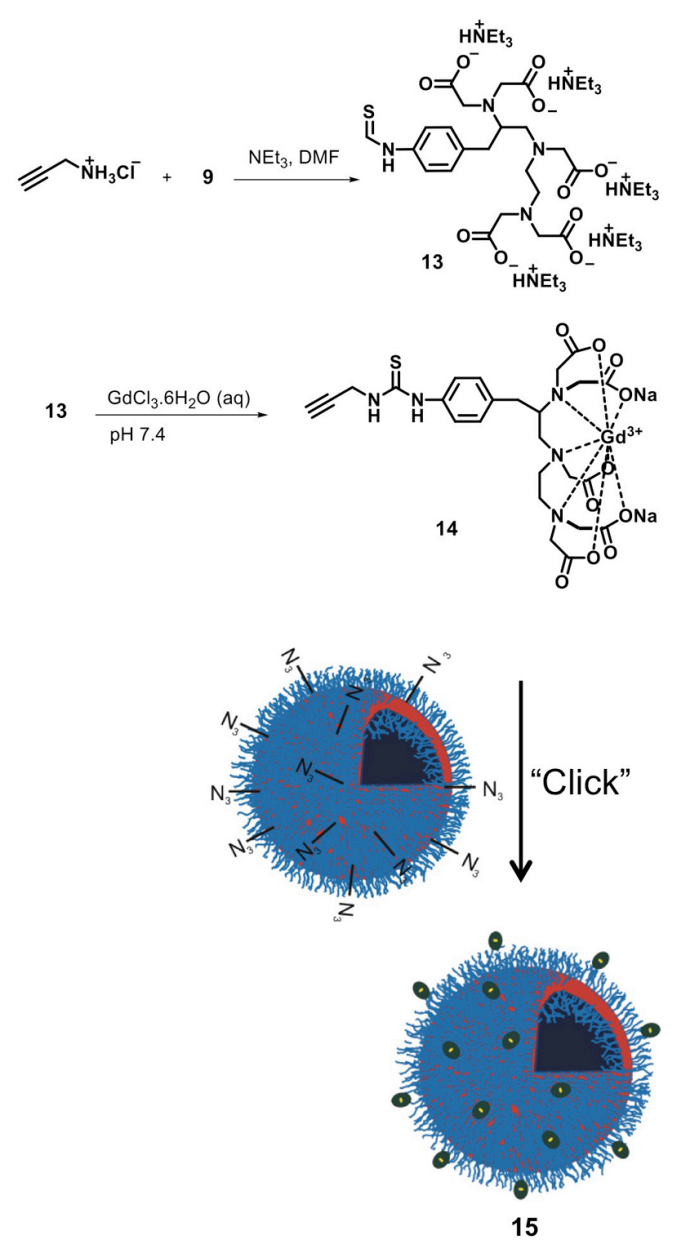

FIGURE 12 - Preparation of a) dendritic Gd(III) and dendritic Gd(III) functionalized polymersomes; b) non-dendritic Gd(III) and non-dendritic Gd(III) functionalized polymersomes. 
non-dendritic polymersomes was also likely due to the hindered motion of the complexes at the vesicle surface, as well as the slow tumbling rate of the entire vesicle system, though the PEO chains introduce some flexibility to the system. When both the dendritic and polymer components were combined in $\mathbf{1 2}$, the resulting $r_{1}$ was the highest reported for a polymersome agent. The additive effect can result from the availability of the chelates at the vesicle surface for water exchange, the hindered motion of the Gd(III) chelate at the local level imparted by the dendritic structure, and the large size and thus slow tumbling rate of the polymersome at the nanoscale level. Thus, this study demonstrated that different nanoscale components can be readily combined to provide additive effects on relaxivity, while at the same time providing opportunities to exploit the multifunctional potential of polymersomes.

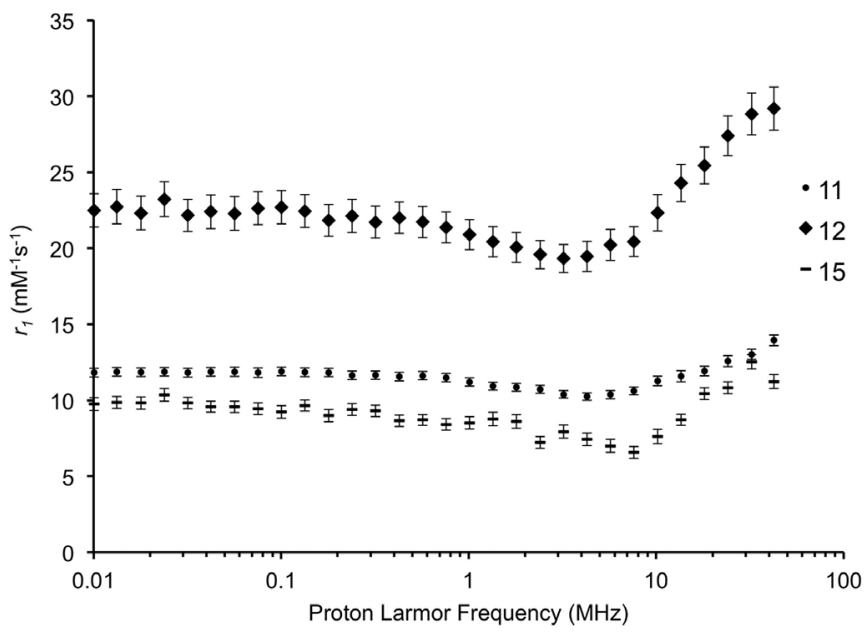

FIGURE 13 - Longitudinal relaxivity $\left(r_{1}\right)$ of dendron 11, polymersome 12, and polymersome 15 in phosphate buffer $(0.1$ $\mathrm{M}, \mathrm{pH}$ 7.4) as a function of field strength at $298 \mathrm{~K}$.

\section{CONCLUDING REMARKS AND FUTURE DI- RECTIONS}

A method has been developed for the conjugation of dendrons to the surfaces of nanomaterials. Thus far, the nanomaterials investigated have been dextran coated SPIO, PBD-PEO polymersomes and PCL-PEO polymersomes and micelles, while the dendrons can have peripheral hydroxys, amines, guanidines, carbohydrates or metal chelates. The only requirement is the presence of azide moieties on the surface of the nanomaterial and an alkyne at the focal point of the dendron, so it is a highly versatile strategy. In general, it has been found that the yields of the azide + alkyne [3+2] cycloaddition reactions are high when the densities of azides on the nanomaterial surface are relatively low, while at higher densities the yields become lower, which is believed to result from steric hindrance at the surface. Most dendron-functionalized materials retained their original morphologies and remained well dispersed in solution. However PCL-PEO polymersomes exhibited a tendency to aggregate upon the conjugation of cationic dendrons.

An advantage of this dendritic functionalization strategy is that because of the multivalency of dendrons, it is an efficient means of significantly altering the surface chemistry of a material in a single step, without changing the core composition of the material. This has been used to study the effects of surface chemistry on the properties of materials. In vitro studies have shown that release kinetics of small and large molecules, toxicity, and cell uptake are unaffected by changing the surface groups of polymersomes with the exception of dendritic guanidines, which imparted cell penetrating properties. Though these dendritic guanidines do impart moderate levels of toxicity at higher concentrations, they have proved to be a versatile approach for enhancing the delivery of SPIO, vesicles, and micelles into cells. This can provide important functions such as enhancing the sensitivity of MRI and improving the delivery of encapsulated drug molecules into cells. Another important function that has been demonstrated is the enhancement in binding of dendritic ligands to protein targets, which has implications for both targeted delivery and multivalent therapeutics. In addition, a significant enhancement in the relaxivity of an MRI contrast agent was achieved using a dendritic vesicle system.

Future work will include the continued application of the dendritic functionalization approach to the development of new functional materials. For example, while the enhancement in protein binding of dendritic ligands was demonstrated with mannose, there are numerous other ligands such as carbohydrates and peptides that can provide enhanced therapeutic and targeting efficacy when presented in a multivalent manner. Furthermore, it will be important to exploit the multifunctionality of materials such as vesicles where in addition to the surface functionalization, therapeutics and/or imaging agents can be incorporated into the membrane or core.

\section{ACKNOWLEDGEMENTS}

We thanks the Natural Science and Engineering Research Council of Canada (NSERC) Discovery Grant Program, the Canada Research Chairs Program, and the Government of Ontario (scholarship to A. N.) for funding this work. 


\section{REFERENCES}

ACCARDO, A.; TESAURO, D.; ROSCIGNO, P.; GIANOLIO, E.; PADUANO, L.; D'ERRICO, G.; PEDONE, C.; MORELLI, G. Physicochemical properties of mixed micellar aggregates containing CCK peptides and $\mathrm{Gd}$ complexes designed as tumor specific contrast agents in MRI. J. Am. Chem. Soc., v.126, n.10, p.3097-3107, 2004.

AHMED, F.; PAKUNLU, R.I.; SRINIVAS, G.; BRANNAN, A.; BATES, F.; KLEIN, M.L.; MINKO, T.; DISCHER, D.E. Shrinkage of a rapidly growing tumor by drug-loaded polymersomes: $\mathrm{pH}$-triggered release through copolymer degradation. Mol. Pharmaceutics, v.3, n.3, p.340-350, 2006.

ALEXANDRIDIS, P.; LINDMAN, B. Amphiphilic block copolymers: self-assembly and applications. Amsterdam, New York: Elsevier, 2000. 448 p.

ALLEN, M.J.; RAINES, R.T.; KIESSLING, L.L. Contrast agents for magnetic resonance imaging synthesized with ring-opening metathesis polymerization. J. Am. Chem. Soc., v.128, n.20, p.6534-6535, 2006.

AMOS, R.C.; NAZEMI, A.; BONDUELLE, C.V.; GILLIES, E.R. Tuning polymersome surfaces: functionalization with dendritic groups. Soft Matter, v.8, n.21, p.5947-5958, 2012.

AULENTA, F.; HAYES, W.; RANNARD, S. Dendrimers: a new class of nanoscopic containers and delivery devices. Eur. Polym. J., v.39, n.9, p.1741-1771, 2003.

BALMERT, S.C.; LITTLE, S.R. Biomimetic delivery with micro- and nanoparticles. Adv. Mater., v.24, n.28, p.3757$3778,2012$.

BECK-BROICHSITTER, M.; MERKEL, O.M.; KISSEL, T. Controlled pulmonary drug and gene delivery using polymeric nano-carriers. J. Controlled Release, v.161, n.2, p.214-224, 2012.

BITTIGER, H.; SCHNEBLI, H.P. Concanavalin A as a tool. London, New York: John Wiley and Sons, Ltd., 1976. 639 p.

BULTE, J.W.M.; DOUGLAS, T.; WITWER, B.; ZHANG, S.C.; STRABLE, E.; LEWIS, B.K.; ZYWICKE, H.; MILLER, B.; VAN GELDEREN, P.; MOSKOWITZ, B.M.; DUNCAN, I.D.; FRANK, J.A. Magnetodendrimers allow endosomal magnetic labeling and in vivo tracking of stem cells. Nat. Biotechnol., v.19, n.12, p.1141-1147, 2001.
CAI, S.; VIJAYAN, K.; CHENG, D.; LIMA, E.M.; DISCHER, D.E. Micelles of different morphologies - advantages of work-like filomicelles of PEO-PCL in paclitaxel delivery. Pharm. Res., v.24, n.11, p.2099-2109, 2007.

CAMINADE, A.; LAURENT, R.; MAJORAL, J. Characterization of dendrimers. Adv. Drug Delivery Rev., v.57, n.15, p.2130-2146, 2005.

CARAVAN, P. Strategies for increasing the sensitivity of gadolinium based MRI contrast agents. Chem. Soc. Rev., v.35, n.6, p.512-523, 2006.

CARAVAN, P.; CLOUTIER, N.J.; GREENFIELD, M.T.; MCDERMID, S.A.; DUNHAM, S.U.; BULTE, J.W.M.; AMEDIO JR., J.C.; LOOBY, R.J.; SUPKOWSKI, R.M.; HORROCKS JR., W.D.; MCMURRY, T.J.; LAUFFER, R.B. The interaction of MS-325 with human serum albumin and its effect on proton relaxation rate. J. Am. Chem. Soc., v.124, n.12, p.3152-3162, 2002.

CARAVAN, P.; ELLISON, J.J.; MCMURRY, T.J.; LAUFFER, R.B. Gadolinium (III) chelates as MRI contrast agents: structure, dynamics, and applications. Chem. Rev., v.99, n.9, p.2293-2352, 1999.

CHANDRA, R.; RUSTGI, R. Biodegradable polymers. Prog. Polym. Sci., v.23, n.7, p.1273-1335, 1998.

CHENG, R.; FENG, F.; MENG, F.; DENG, C.; FEIJEN, J.; ZHONG, Z. Glutathione-responsive nano-vehicles as a promising platform for targeted intracellular drug and gene delivery. J. Control.Release, v.152, n.1, p.2-12, 2011.

CHENG, R.; MENG, F.; MA, S.; XU, H.; LIU, H.; JING, X.; ZHONG, Z. Reduction and temperature dual-responsive crosslinked polymersomes for targeted intracellular protein delivery. J. Mater. Chem., v.21, n.47, p.19013-19020, 2011.

CHENG, Z.; TSOURKAS, A. Paramagnetic porous polymersomes. Langmuir, v.24, n.15, p.8169-8173, 2008.

CHOUDHURY, N.N.; HE, H. Nanocarriers for the simultaneous co-delivery of therapeutic genes and anticancer drugs. Curr. Pharm. Biotechnol., v.13, n.7, p.1317-1331, 2012.

CHRISTIAN, D.A.; CAI, S.; BOWEN, D.M.; KIM, Y.; PAJEROWSKI, J.D.; DISCHER, D.E. Polymersome carriers: from self-assembly to siRNA and protein therapeutics. Eur. J. Pharm. Biopharm., v.71, n.3, p.463474, 2009. 
CHUNG, H.H.; HARMS, G.; SEONG, C.M.; CHOI, B.H.; MIN, C.; TAULANE, J.P.; GOODMAN, M. Dendritic oligoguanidines are intracellular translocators. Biopolymers, v.76, n.1, p.83-96, 2004.

CINTEZA, L.O. Quantum dots in biomedical applications: advances and challenges. J. Nanophotonics, v.4, p.1-36, 2010 .

CORNELISSEN, J.J.L.M.; FISCHER, M.; SOMMERDIJK, N.A.J.M.; NOLTE, R.J.M. Helical superstructures from charged poly(styrene)-poly(isocyanodipeptide) block copolymers. Science, v.280, n.5368, p.1427-1430, 1998.

COROT, C.; ROBERT, P.; IDEE, J.M.; PORT, M. Recent advances in iron oxide nanocrystal technology for medical imaging. Adv. Drug Delivery Rev., v.58, n.14, p.1471-1504, 2006.

CUI, H.; CHEN, Z.; ZHONG, S.; WOOLEY, K.L.; POCHAN, D.J. Block copolymer assembly via kinetic control. Science, v.317, n.5838, p.647-650, 2007.

DEMIRGOZ, D.; PANGBURN, T.O.; DAVIS, K.P.; LEE, S.; BATES, F.S.; KOKKOLI, E. PR_b-targeted delivery of tumor necrosis factor-alpha by polymersomes for the treatment of prostate cancer. Soft Matter, v.5, n.10, p.20112019, 2009.

DISCHER, B.M.; WON, Y.Y.; EGE, D.S.; LEE, J.C.M.; BATES, F.S.; DISCHER, D.E.; HAMMER, D.A. Polymersomes: tough vesicles made from diblock copolymers. Science, v.284, n.5417, p.1143-1145, 1999.

DISCHER, D.E.; EISENBERG, A. Polymer vesicles. Science, v.297, n.5583, p.967-973, 2002.

DYKMAN, L.; KHLEBTSOV, N. Gold nanoparticles in biomedical applications: recent advances and perspectives. Chem. Soc. Rev., v.41, n.6, p.2256-2282, 2012.

FOSTER, P.J.; DUNN, E.A.; KARL, K.E.; SNIR, J.A.; NYCZ, C.M.; HARVEY, A.J.; PETTIS, R.J. Cellular magnetic resonance imaging: in vivo imaging of melanoma cells in lymph nodes of mice. Neoplasia, v.10, n.3, p.207-216, 2008.

FRANK, J.A.; MILLER, B.R.; ARBAB, A.S.; ZYWICKE, H.A.; JORDAN, E.K.; LEWIS, B.K.; BRYANT JR, L.H.; BULTE, J.W.M. Clinically applicable labeling of mammalian and stem cells by combining superparamagnetic iron oxides and transfection agents. Radiology, v.228, n.2, p.480-487, 2003.
FRECHET, J.M.J.; TOMALIA, D.E. Dendrimers and other dendritic polymers. Chichester, New York: Wiley and Sons, 2002. 688 p.

FRESHNEY, R.I. (Ed.). Culture of animal cells: a manual of basic technique. 4.ed. New York: Wiley-Liss, 2000. 486 p.

GANG, Y.; YAMASHITA, M.; TIAN, M.; ZHANG, H.; OZAKI, N.; YAMASHITA, J.; FUJIE, M.; TAKEHAR, Y.; SAKAHARA, H. The development of dendritic Gd-DTPA complexes for MRI contrast agents. Curr. Med. Imaging Rev., v.6, n.1, p.42-45, 2010.

GESTWICKI, J.E.; CAIRO, C.W.; STRONG, L.E.; OETJEN, K.A.; KIESSLING, L.L. Influencing receptor-ligand binding mechanisms with multivalent ligand architecture. J. Am. Chem. Soc., v.124, n.50, p.14922-14933, 2002.

GHOROGHCHIAN, P.P.; FRAIL, P.R.; SUSUMU, K.; BLESSINGTON, D.; BRANNAN, A.K.; BATES, F.S.; CHANCE, B.; HAMMER, D.A.; THERIEN, M.J. Nearinfrared-emissive polymersomes: self-assembled soft matter for in vivo optical imaging. Proc. Natl. Acad. Sci. U.S.A., v.102, n.8, p.2922-2927, 2005.

GILLIES, E.R.; DY, E.; FRÉCHET, J.M.J.; SZOKA, F.C. Biological evaluation of polyester dendrimer-poly(ethylene oxide) "bow-tie" hybrids with tunable molecular weight and architecture. Mol. Pharmaceutics, v.2, n.2, p.129-138, 2005.

GILLIES, E.R.; FRÉCHET, J.M.J. Dendrimers and dendritic polymers in drug delivery. Drug Discov.Today, v.10, n.1, p.35-43, 2005.

GRÜLL, H.; LANGEREIS, S.; MESSAGER, L.; CASTELLI, D.D.; SANINO, A.; TORRES, E.; TERRENO, E.; AIME, S. Block copolymer vesicles containing paramagnetic lanthanide complexes: a novel class of T(1)- and CEST MRI contrast agents. Soft Matter, v.6, n.19, p.4847-4850, 2010.

HELMS, B.; MYNAR, J.L.; HAWKER, C.J.; FRÉCHET, J.M.J. Dendronized linear polymers via "click chemistry". J. Am. Chem. Soc., v.126, n.46, p.15020-15021, 2004.

HEYN, C.; RONALD, J.A.; MACKENZIE, L.T.; MACDONALD, I.C.; CHAMBERS, A.F.; RUTT, K.; FOSTER, P.J. In vivo magnetic resonance imaging of single cells in mouse brain with optical validation. Magn. Res. Med., v.55, n.1, p.23-29, 2006. 
HOOKER, J.M.; DATTA, A.; BOTTA, M.; RAYMOND, K.N.; FRANCIS, M.B. Magnetic resonance contrast agents from viral capsid shells: a comparison of exterior and interior cargo strategies. Nano Lett., v.7, n.8, p.2207-2210, 2007.

HUANG, K.; VOSS, B.; KUMAR, D.; HAMM, H.E.; HARTH, E. Dendritic molecular transporters provide control of delivery to intracellular compartments. Bioconjugate Chem., v.18, n.2, p.403-409, 2007.

JAIN, K.; KESHARWANI, P.; GUPTA, U.; JAIN, N.K. Dendrimer toxicity: let's meet the challenge. Int. J. Pharm., v.394, n.1-2, p.122-142, 2010.

JENKINS, M.J.; HARRISON, K.L.; SILVA, M.; WHITAKER, M.J.; SHAKESHEFF, K.M.; HOWDLE, S.M. Characterisation of microcellular foams produced from semi-crystalline PCL using supercritical carbon dioxide. Eur. Polym. J., v.42, n.11, p.3145-3151, 2006.

JOSEPHSON, L.; TUNG, C.; MOORE, A.; WEISSLEDER, R. High-efficiency intracellular magnetic labeling with novel superparamagnetic-Tat peptide conjugates. Bioconjugate Chem., v.10, n.2, p.186-191, 1999.

KANAI, M.; MORTELL, K.H.; KIESSLING, L.L. Varying the size of multivalent ligands: the dependence of concanavalin A binding on neoglycopolymer length. Biochemistry, v.119, n.41, p.9931-9932, 1997.

KOBAYASHI, H.; BRECHBIEL, M.W. Nano-sized MRI contrast agents with dendrimer cores. Adv. Drug Delivery Rev., v.57, n.15, p.2271-2286, 2005.

LAM, C.X.F.; TEOH, S.H.; HUTMACHER, D.W. Comparison of the degradation of polycaprolactone and polycaprolactone-(beta-tricalcium phosphate) scaffolds in alkaline medium. Polym. Int., v.56, n.6, p.718-728, 2007.

LAURENT, S.; FORGE, D.; PORT, M.; ROCH, A.; ROBIC, C.; VANDER ELST, L.; MULLER, R.N. Magnetic iron oxide nanoparticles: synthesis, stabilization, vectorization, physicochemical characterizations, and biological applications. Chem. Rev., v.108, n.6, p.2064-2110., 2008.

LEE, J.H.; HUH, Y.M.; JUN, Y.W.; SEO, J.W.; JANG, J.T.; SONG, H.T.; KIM, S.; CHO, E.J.; YOON, H.G.; SUH, J.S.; CHEON, J. Artificially engineered magnetic nanoparticles for ultra-sensitive molecular imaging. Nat. Med., v.13, n.1, p.95-99, 2007.
LEROUEIL, P.R.; BERRY, S.A.; DUTHIE, K.; HAN, G.; ROTELLO, V.M.; MCNERNY, D.Q.; BAKER JR, J.R.; ORR, B.G. Wide varieties of cationic nanoparticles induce defects in supported lipid bilayers. Nano Lett., v.8, n.2, p.420-424, 2008.

LEWIN, M.; CARLESSO, N.; TUNG, C.H.; TANG, X.W.; CORY, D.; SCADDEN, D.T.; WEISSLEDER, R. Tat peptide-derivatized magnetic nanoparticles allow in vivo tracking and recovery of progenitor cells. Nat. Biotechnol., v.18, n.4, p.410-414, 2000.

LI, B.; MARTIN, A.; GILLIES, E.R. Multivalent polymer vesicles via surface functionalization. Chem. Commun., v.48, p.5217-5219, 2007.

LI, Z.; WEI, L.; GAO, M.; LEI, H. One-pot reaction to synthesize biocompatible magnetite nanoparticles. $A d v$. Mater., v.17, n.8, p.1001-1005, 2005.

LIN, J.J.; SILAS, J.A.; BERMUDEZ, H.; MILAM, V.T.; BATES, F.S.; HAMMER, D.A. The effect of polymer chain length and surface density on the adhesiveness of functionalized polymersomes. Langmuir, v.20, n.13, p.5493-5500, 2004

LIU, G.J.; MA, S.B.; LI, S.K.; CHENG, R.; MENG, F.H.; LIU, H.Y.; ZHONG, Z.Y. The highly efficient delivery of exogenous proteins into cells mediated by biodegradable chimaeric polymersomes. Biomaterials, v.31, n.29, p.7575$7585,2010$.

LOMAS, H.; CANTON, I.; MACNEIL, S.; DU, J.; ARMES, S.P.; RYAN, A.J.; LEWIS, A.L.; BATTAGLIA, G. Biomimetic $\mathrm{pH}$ sensitive polymersomes for efficient DNA encapsulation and delivery. Pharmaceuticals, v.19, n.23, p.4238-4243, 2007.

LUNDQUIST, J.J.; TOONE, E.J. The cluster glycoside effect. Chem. Rev., v.102, n.2, p.555-578, 2002.

LUTZ, J.-F.; ZARAFSHANI, Z. Efficient construction of therapeutics, bioconjugates, biomaterials and bioactive surfaces using azide-alkyne "click" chemistry. Adv. Drug Delivery Rev., v.60, n.9, p.958-970, 2008

MAMMEN, M.; CHOI, S.K.; WHITESIDES, G.M. Polyvalent interactions in biological systems: implications for design and use of multivalent ligands and inhibitors. Angew. Chem. Int. Ed., v.37, n.20, p.2754-2794, 1998. 
MARTIN, A.L.; BERNAS, L.; FOSTER, P.F.; RUTT, B.K.; GILLIES, E.R. Enhanced cell uptake of superparamagnetic iron oxide nanoparticles functionalized with dendritic guanidines. Bioconjugate Chem., v.19, n.12, p.2375-2384, 2008 .

MARTIN, A.L.; LI, B.; GILLIES, E.R. Surface functionalization of nanomaterials with dendritic groups: towards enhanced binding to biological targets. J. Am. Chem. Soc., v.131, n.2, p.734-741, 2009.

MEDINA, S.H.; EL-SAYED, M.E.H. Dendrimers as carriers for delivery of chemotherapeutic agents. Chem. Rev., v.109, n.7, p.2859-3208, 2009.

MERBACH, A.E.; TOTH, E. The chemistry of contrast agents in medical magnetic resonance imaging. Chichester: John Wiley and Sons, 2001. ??? p.

NAZEMI, A.; AMOS, R.C.; BONDUELLE, C.V.; GILLIES, E.R. Dendritic surface functionalization of biodegradable polymer assemblies. J. Polym. Sci. Part A: Polym. Chem., v.49, n.12, p.2546-2559, 2011.

NAZEMI, A.; MARTINEZ, F.; SCHOLL, T.J.; GILLIES, E.R. Biodegradable dendritic polymersomes as modular, high-relaxivity MRI contrast agents. RSC $A d v$., v.2, n.21, p.7971-7973, 2012.

NEWKOME, G.R.; MOOREFIELD, C.N.; VOGTLE, F. Dendrimers and dendrons: concepts, syntheses, applications. Weinheim: Wiley-VCH, 2001. 623 p.

OHYA, Y.; TAKAHASHI, A.; NAGAHAMA, K. Biodegradable polymeric assemblies for biomedical materials. Adv. Polym. Sci., v.247, p.65-114, 2012.

PANG, Z.; FENG, L.; HUA, R.; CHEN, J.; GAO, H.; PAN, S.; JIANG, X.; ZHANG, P. Lactoferrin-conjugated biodegradable polymersome holding doxorubicin and tetrandrine for chemotherapy of glioma rats. Mol. Pharmaceutics, v.7, n.6, p.1995-2005, 2010.

PATEL, T.; ZHOU, J.; PIEPMEIER, J.M.; SALTZMAN, W.M. Polymeric nanoparticles for drug delivery to the central nervous system. Adv. Drug Delivery Rev., v.64, n.7, p.701$705,2012$.
PITTET, M.J.; SWIRSKI, P.K.; REYNOLDS, F.; JOSEPHSON, L.; WEISSLEDER, R. Labeling of immune cells for in vivo imaging using magnetofluorescent nanoparticles. Nat. Protoc., v.1, n.1, p.73-78, 2006.

POCHAN, D.J.; CHEN, Z.; CUI, H.; HALES, K.; QI, K.; WOOLEY, K.L. Toroidal triblock copolymer assemblies. Science, v.306, n.5693, p.94-97, 2004.

PRINCE, M.R.; ZHANG, H.L.; RODITI, G.H.; LEINER, T.; KUCHARCZYK, W. Risk factors for NSF: a literature review. J. Magn. Reson. Imaging, v.30, n.6, p.1298-1308, 2009.

RAI, P.; PADALA, C.; POON, V.; SARAPH, A.; BASHA, S.; KATE, S.; TAO, K.; MOGRIDGE, J.; KANE, R.S. Statistical pattern matching facilitates the design of polyvalent inhibitors of anthrax and cholera toxins. Toxicology, v.24, n.5, p.582-586, 2006.

RANQUIN, A.; VERSÉES, W.; MEIER, W.; STEYAERT, J.; VAN GELDER, P. Therapeutic nanoreactors: combining chemistry and biology in a novel triblock copolymer drug delivery system. Nano Lett., v.5, n.11, p.2220-2224, 2005.

ROLLAND, O.; TURRIN, C.-O.; CAMINADE, A.-M.; MAJORAL, J.-P. Dendrimers and nanomedicine: multivalency in action. New J. Chem., v.33, n.9, p.18091824, 2009.

ROY, R. Syntheses and some applications of chemically defined multivalent glycoconjugates. Curr. Opin. Struct. Biol., v.6, n.5, p.692-702, 1996.

SCHÜHLE, D.T.; VAN RIJN, P.; LAURENT, S.; VANDER ELST, L.; MULLER, R.N.; STUART, M.C.A.; SCHATZ, J.; PETERS, J.A. Liposomes with conjugates of a calix[4] arene and a Gd-DOTA derivative on the outside surface; an efficient potential contrast agent for MRI. Chem. Commun., v.46, n.24, p.4399-4401, 2010.

SINHA, V.R.; BANSAL, K.; KAUSHIK, R.; KUMRIA, R.; TREHAN, A. Poly-epsilon-caprolactone microspheres and nanospheres: an overview. Int. J. Pharm., v.278, n.1, p.1-23, 2004.

TERRENO, E.; DELLI CASTELLI, D.; VIALE, A.; AIME, $\mathrm{S}$. Challenges for molecular magnetic resonance imaging. Chem. Rev., v.110, n.5, p.3019-3042, 2010. 
TIAN, B.; TAO, X.; REN, T.; WENG, Y.; LIN, X.; ZHANG, Y.; TANG, X. Polypeptide-based vesicles: formation, properties and application for drug delivery. J. Mater. Chem., v.22, n.34, p.17404-17414, 2012.

TOMALIA, D.A.; BAKER, H.; DEWALD, J.; HALL, M.; KALLOS, G.; MARTIN, S.; ROECK, J.; RYDER, J.; SMITH, P. A new class of polymers: starburst-dendritic macromolecules. Eur. Polym. J., v.17, n.1, p.117-132, 1985.

TOMALIA, D.A.; NAYLOR, A.M.; GODDARD, W.A. Starburst dendrimers: molecular-level control of size, shape, surface chemistry, topology, and flexibility from atoms to macroscopic matter. Angew. Chem. Int. Ed., v.29, n.2, p.138-175, 1990.

TORCHILIN, V.P.; WEISSIG, V. Liposomes. Oxford: Oxford University Press, 2003. 420 p.

TSOURKAS, A.; SHINDE-PATIL, V.R.; KELLY, K.A.; PATEL, P.; WOLLEY, A.; ALLPORT, J.R.; WEISSLEDER, R. In vivo imaging of activated endothelium using an antiVCAM-1 magnetooptical probe. Bioconjugate Chem., v.16, n.3, p.576-581, 2005.

VILLARAZA, A.J.L.; BUMB, A.; BRECHBIEL, M.W. Macromolecules, dendrimers, and nanomaterials in magnetic resonance imaging: the interplay between size, function, and pharmacokinetics. Chem. Rev., v.110, n.5, p.2921-2959, 2010.
WEISSLEDER, R.; BOGDANOC, A.; NEUWELT, E.A.; PAPISOV, M. Long-circulating iron oxides for MR imaging. Adv. Drug Delivery Rev., v.16, n.2-3, p.321-334, 1995.

WENDER, P.A.; KREIDER, E.; PELKEY, E.T.; ROTHBARD, J.; VANDEUSEN, C.L. Dendrimeric molecular transporters: synthesis and evaluation of tunable polyguanidino dendrimers that facilitate cellular uptake. Org. Lett., v.7, n.22, p.4815-4818, 2005.

WU, P.; MALKOCH, M.; HUNT, J.N.; VESTBERG, R.; KALTGRAD, E.; FINN, M.G.; FOKIN, V.V.; SHARPLESS, K.B.; HAWKER, C.J. Multivalent, bifunctional dendrimers prepared by click chemistry. Chem. Commun., n.46, p.57755777, 2005.

YAN, D.; ZHOU, Y.; HOU, J. Supramolecular self-assembly of macroscopic tubes. Science, v.303, n.5654, p.65-67, 2004.

YANG, X.Q.; GRAILER, J.J.; ROWLAND, I.J.; JAVADI, A.; HURLEY, S.A.; MATSON, V.Z.; STEEBER, D.A.; GONG, S.Q. Multifunctional stable and $\mathrm{pH}$-responsive polymer vesicles formed by heterofunctional triblock copolymer for targeted anticancer drug delivery and ultrasensitive MR imaging. ACS Nano, v.4, n.11, p.6805-6817, 2010.

ZHANG, L.; EISENBERG, A. Multiple morphologies of |"crew-cut|" aggregates of polystyrene-b-poly(acrylic acid) block copolymers. Science, v.268, n.5218, p.1728-1731, 1995. 